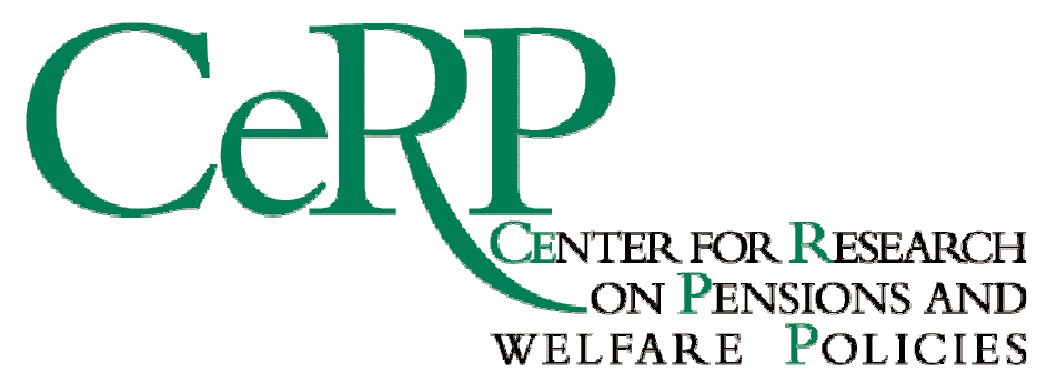

Working Paper 159/16

\title{
SELF-EMPLOYMENT IN ITALY: THE ROLE OF SOCIAL SECURITY WEALTH
}

\author{
Margherita Borella \\ Michele Belloni
}




\title{
Self-Employment in Italy: the Role of Social Security Wealth
}

\author{
Margherita Borella \\ (University of Torino, CeRP-Collegio Carlo Alberto and Netspar) \\ and \\ Michele Belloni \\ (University Ca' Foscari of Venezia, CeRP-Collegio Carlo Alberto and Netspar)
}

This version: $18 / 03 / 2016$

\begin{abstract}
Using a rich micro dataset drawn from administrative archives, we explore whether Social Security Wealth (SSW) is an important factor affecting the decision to become self-employed. We focus on the two main categories of self-employed professions covered by the Italian public pension system: craftsmen and shopkeepers. We use the large exogenous variation in individual expected SSW that occurred as a result of the policy reform process undertaken in Italy during the 1990s to identify the effect of this variable and we study how the probability of being self-employed or employed depends, amongst other things, on the difference in the expected SSW that accrues under the two alternative employment scenarios. Our key finding is that a higher difference in expected SSW from self-employment compared to employment has a positive effect on the probability of being self-employed and on the probability of switching to selfemployment, while it has a negative effect on the probability of switching from selfemployment to employment. We also study how these effects vary with age and, in general, we find that the effect is, in absolute terms, stronger at younger and older ages.
\end{abstract}

JEL codes: J26, J62, L26, H55

Keywords: Self-employment, Social Security Wealth, Social Security reforms

Corresponding Author: Margherita Borella (margherita.borella@unito.it, tel: +390116706088; fax: +390116062) University of Torino, Dipartimento di Scienze Economico-Sociali e MatematicoStatistiche, Corso Unione Sovietica 218bis I-10134 Torino (Italy)

We would like to thank Mariacristina De Nardi, Stefan Hochguertel, Mauro Mastrogiacomo, and the participants at the Netspar International Pension Workshop (Leiden, 2016) for their helpful comments. The financial support from the Netspar Large Vision grant "A 'second and a half' pillar for the selfemployed?" is gratefully acknowledged. 


\section{Introduction}

Small businesses are acknowledged to play an important role in sustaining economic growth and employment (OECD, 2014). On this basis, they are often supported by governments, through regulations and taxes. Studying the effects of government policy instruments on self-employment is thus of some importance.

In Italy, the self-employment rate has historically been high, mainly due to a high percentage of craftsmen and shopkeepers (OECD, 2014). These two groups of selfemployed workers, together with farmers, have benefited from financial support though various channels, including the public pension system, which became particularly generous after a major reform was implemented in 1990. Problems concerning the financial sustainability of the public pension system, however, prompted a series of reforms which then greatly reduced the generosity of the benefits for various categories of workers, including the self-employed. The effect of the reforms implemented in the 1990s on expected Social Security Wealth (SSW) has been uneven across generations and categories of workers.

In this work, we explore if Social Security Wealth is an important factor affecting the decision to become self-employed in Italy ${ }^{1}$. Thanks to the exogenous variability induced by the reforms, we are able to identify the effect of public pension wealth on the probability of being self-employed. We use administrative data, which enables us to compute public pension wealth extremely specifically, as the data contains the complete work history of a sample of private sector workers covered by the public pension system. The vast majority of workers in Italy fall into this category.

There is a great deal of literature on the determinants of self-employment. Our study relates, in particular, to works studying how institutional factors affect selfemployment. Quinn (1980) studies the retirement and labour supply patterns of the selfemployed and employees in response to retirement policies, while Long (1982), Blau (1987) and Scheutze (2000) consider the role of taxes. Blanchflower (2000) studies the determinants of self-employment trends in OECD countries. Using panel data, Bruce (2000) and Hansson (2012) study how the individual decision to transition from employment to self-employment depends on average and marginal tax rates. Zissimopoulos and Karoly (2007) find that, conditional upon other characteristics, Social Security Wealth at age 62 is not significantly related to transitions to selfemployment, neither for men nor women. Also related to our work, Li et al. (2015) isolate the causal effect of wealth on the transition from employment to self-

\footnotetext{
${ }^{1}$ We refer to Social Security Wealth or public pension wealth interchangeably. It is important to clarify as early as at this stage that, until recently, the Italian pension system was a single tier type, with income from occupational pension schemes representing a very tiny share of individuals' pension wealth, both for employees and for a very large majority of the self-employed.
} 
employment and find that an exogenous reduction in pension wealth significantly decreases the probability of transitioning from wage-employment to self-employment.

Our study is based on a large panel of administrative data drawn from the archive of the main Italian social security scheme (National Institute of Social Security, Istituto Nazionale di Previdenza Sociale, INPS). INPS manages the Social Security accounts for various categories of private workers, including employees, craftsmen, shopkeepers, farmers and other smaller categories. Given the nature of our data, we are able to analyse both the self-employment rate, i.e. the probability of an individual being self-employed rather than employed, and the probabilities of switching from employment to self-employment and vice versa. An analysis of the self-employment rate is able to estimate the probability of an individual being self-employed rather than an employee in any given period, which is the combined probability that a worker switched to self-employment at some time and survived until that time period. While this analysis is mainly descriptive, it provides a useful illustration of the data and allows for a comparison to be made with previous studies analysing the self-employment rate. With the benefit of a long panel dataset, we are also able to estimate the transition probabilities, i.e. the probability of a wage worker switching to self-employment, and of a self-employed worker switching to wage employment.

We have a large sample size - about 9 million person-year observations - which is especially important when studying transition probabilities, since persistency in the same pension scheme is extremely high. Moreover, the panel nature of the data allows us to control for unobserved determinants of an individual's self-employment status and its dynamics, such as risk aversion.

We concentrate our analysis on the two main categories of self-employed workers covered by INPS - craftsmen and shopkeepers - which share the same Social Security rules and can be treated as a single category. We thus study how the probability of being (or becoming) self-employed or employed depends, amongst other things, on the difference in expected SSW that can be accrued in the two alternative employment scenarios, i.e. the difference between the expected SSW for selfemployment and the expected SSW for wage employment. In other words, we test if Social Security rules favourable to the self-employed as opposed to employees encourage self-employment. Participation in the public pension system is compulsory and the difference in expected SSW reflects the respective convenience of participating in either scheme. Other things being equal, a rational worker will choose the sector with the highest expected SSW.

Our key finding is that the difference in expected SSW does indeed affect both the probability of being in self-employment and the probability of switching in or out of self-employment. In particular, a higher difference in expected SSW from selfemployment as opposed to employment has a positive effect on the probability of being 
in self-employment and on the probability of switching to self-employment, while it has a negative effect on the probability of switching from self-employment to employment. We also study how these effects vary with age and, in general, we find that the effect is, in absolute terms, stronger at younger and older ages.

The rest of the paper is organised as follows: in section 2 we review the related literature, in section 3 we outline the evolution of Italian pension legislation and in section 4 we describe our empirical strategy. In section 5 we describe our data set and in section 6 we present our results when estimating expected Social Security Wealth. In section 7 we present the results of our econometric analysis based on the pooled sample, while in sections 8 and 9 we study transitions from employment to self-employment and vice versa. Section 10 concludes the paper.

\section{Related literature}

The literature on self-employment analyses both the factors explaining selfemployment rates and the determinants of the decision to become self-employed. Studies focusing on self-employment rates include both time series analysis (Blau, 1987) and cross-sectional studies (Scheutze, 2000). This literature typically concentrates on factors affecting the evolution of self-employment rates. These include shifts in the composition of industries' employment shares towards industries where selfemployment is more prevalent, as in the case of service production (Blau, 1997), shifts in the demographic composition of the workforce (Crompton, 1993) as well as institutional factors, most notably income tax policy (Scheutze, 2000), minimum wage legislation (Blau, 1987) and also retirement policies (Quinn, 1980). Self-employment rates have also been found to rise with increases in local or national unemployment rates (Blanchflower and Oswald, 1990, Schuetze, 2000, Blanchflower, 2000). More recently, Torrini (2005) studies the role of institutional variables in determining self-employment rates across OECD countries. In particular, he studies the role of taxation, tax evasion opportunities, product market regulation and employment protection legislation.

The individual decision to become self-employed has also been studied, highlighting various factors that may influence such a decision, which may be driven by the positive benefits of being self-employed but also by the poor job prospects of wageemployed or unemployed workers (Blanchflower and Oswald, 1998). Evans and Leighton (1989) find that workers with previous unemployment spells, lower wage workers and workers with a history of job instability are more likely to become selfemployed, a result consistent with the notion that unsuccessful workers are pushed into self-employment (the so-called 'push' hypothesis). Self-employed workers are also found to face liquidity constraints. Using US micro data, Evans and Leighton (1989) and Evans and Jovanovic (1989) find that people with more family assets are likelier to 
switch from wage-employment to self-employment. Blanchflower and Oswald (1998) find that the probability of self-employment depends positively upon whether the individual has ever received an inheritance or gift. Using a quantitative life cycle model with altruism across generations and entrepreneurial choice, Cagetti and De Nardi (2006) analyse the role of borrowing constraints as determinants of entrepreneurial decisions. Their results indicate that voluntary bequests are an important channel allowing some high-ability workers to establish or enlarge an entrepreneurial activity.

Bruce (2000) and Hansson (2012) study how the individual decision to transition from wage-employment to self-employment depends on average and marginal tax rates. Bruce (2002) analyses transitions from self-employment to wage work. Bruce (2000) finds that reducing an individual's marginal tax rate on self-employment income reduces the probability of entry, while reducing his average tax rate increases the probability of switching to self-employment. However, this finding is not universal, as, for example, Hansson (2012) performs a similar analysis using Swedish panel data, and finds that both higher average and marginal taxes have a negative impact on the decision to become self-employed. Stabile (2004) examines the effects of introducing a payroll tax (the Employer Health Tax) into the labour market, which taxes employers, but which exempts the self-employed. Using a time series of cross-sections of Canadian data, he finds that payroll taxes influence the decision to become self-employed, with the probability of self-employment increasing as taxes on employees increase and vice versa.

Zissimopoulos and Karoly (2007) use panel data drawn from the US Health and Retirement Study to study the determinants of labour force transitions to selfemployment at older ages. Their analysis controls for a number of factors, including demographic characteristics, health status, financial and pension wealth. Conditional upon other characteristics, they find that Social Security wealth at age 62 is not significantly related to transitions to self-employment, neither for men nor women. Mastrogiacomo and Belloni (2015) also look at entrepreneurship choices among older workers and conclude that those who shift to self-employment are more motivated employees seeking higher job satisfaction.

The work by Li et al. (2015) is closely related to our study as the authors aim to isolate the causal effect of pension wealth on the transition from wage-employment to self-employment and, to this end, they use a pension system reform in the Netherlands in 2006 as an exogenous variation in pension wealth. After the reform, employees born on or after 1 January 1950 faced a substantial reduction in their pension wealth. Their main empirical results indicate that this exogenous wealth reduction has a significant negative effect on the decision to switch to self-employment: the authors highlight that a possible explanation for this result is that when pension wealth drops, the wageemployed tend to reserve a higher amount of liquid private wealth for retirement and precautionary saving, so less liquid financial wealth will be used to start a new business 
and bear the risk of self-employment, resulting in a reduction of transitions to selfemployment.

Our work also relates to a broader strand of the literature, namely to studies using exogenous changes in SSW to evaluate its effect on economic outcomes, such as the decision to retire (Brugiavini and Peracchi, 2004, Belloni and Alessie, 2009) or to accumulate private wealth through personal savings (Attanasio and Brugiavini, 2003, Attanasio and Rohwedder, 2003). Attanasio and Brugiavini (2003), in particular, provide evidence that saving rates increase as a result of the reduction in pension wealth induced by the Italian pension reforms. They also allow for the possibility that substitutability changes with age, and find that substitutability is particularly high (and precisely estimated) for younger workers.

\section{The evolution of the rules in the Italian pension system}

Pension legislation in Italy is still extremely fragmented, even after the reform process aimed at harmonising the rules that began back in the nineties, a process that is still very much ongoing. The main Social Security institution, INPS (Istituto Nazionale della Previdenza Sociale), covers most of the workers in the private sector: the employed, craftsmen, shopkeepers and farmers. Among the self-employed, many professionals (e.g. lawyers and doctors) are not included because they have independent pension funds, some of which have only very recently been incorporated by INPS as part of the harmonisation process. We focus on the evolution of the pension rules pertaining to craftsmen and shopkeepers, who we label self-employed and who basically share the same rules, and privately employed workers.

In summary, the Italian public pension system is a pay-as-you-go system, with different rules, payroll taxes and benefits applying to the self-employed and to employees. While, until 1990, the self-employed were entitled to a contribution-based benefit, after that year a reform introduced a defined benefit (DB) system, similar to the one already in place for employees but with lower payroll taxes. The 1990 reform greatly increased the Social Security Wealth of the self-employed while leaving it unaffected for employees.

Financial sustainability problems, however, prompted a reform in 1992, which maintained the DB system but tightened the eligibility criteria and the pension benefit rules. While the reform changed the indexation method of the benefits from wages to prices for all categories and with immediate effect, the formulae to compute the pension benefit differed across generations and pension schemes.

In 1995, another major reform triggered a transition to a Notional Defined Contribution (NDC) scheme for all workers, while maintaining differences in payroll 
taxes. The lengthy transition period planned by the reform, which will last until 2030, also implies that its effects are heterogeneous across generations and categories of workers.

The intended effect of these and other minor reforms that have occurred since 1992 was to reduce the generosity of the public pension system for all workers: their effect on expected Social Security Wealth has, however, been uneven for different generations and categories of workers. While we leave a detailed description of the evolution of the rules to the Appendix, in section 6 we show the results of our estimation of expected SSW for different generations of self-employed and employed workers, highlighting how the reforms had heterogeneous effects across different categories of workers.

\section{Empirical strategy}

The aim of the empirical analysis is to test the hypothesis that Social Security Wealth affects the probability of being self-employed rather than employed, as well as the probability of switching from self- to wage-employment and vice versa. As we have the benefit of a long panel dataset, we are able to analyse both the self-employment rate and the transitions from and to self-employment. An analysis of the self-employment rate is able to estimate the probability of an individual being self-employed rather than an employee in any given period, which is the combined probability that a worker switched to self-employment at some time and survived until that time period. This analysis is mainly descriptive, as it does not differentiate the determinants of switching and survival into self-employment (Evans and Leighton, 1989), but in addition to providing a useful illustration of the data, it allows for a comparison to be made with previous studies of the self-employment rate. Having the benefit of a long panel dataset, we are also able to estimate the transition probabilities, the probability of a wage worker switching to self-employment and of a self-employed worker switching to wageemployment.

In both analyses, of statuses and transitions, we define a dichotomous variable self $_{i t+1}$ equal to 1 if a worker is self-employed in period $t+1$, and equal to zero if he is an employee. With our data, we are able to identify two types of self-employed workers, shopkeepers and craftsmen: the Social Security rules are virtually the same across the two groups and we treat them as one single group. In addition, we have information on employees. For all workers, we observe all the information needed to compute their expected public pension as well as the contributions they are expected to pay $^{2}$. The

${ }^{2}$ While the archive records all spells of work in some schemes, it lacks information on other, compulsory, schemes. Most importantly, public sector employees are not covered, like many other occupations covered by compulsory private pension schemes (such as lawyers, doctors or journalists, to name a few examples). As a consequence, when a worker is not covered by the archive (possibly 
administrative data, however, lacks important information on marital status, family, education and so on. For this reason, our estimates are based on a linear probability model, which allows us to control for unobserved time-invariant factors, including preferences toward risk. Our estimated equation closely follows the work of Bruce (2000, 2002) and Hansson (2012), who study how variations in tax rates affect the probability of becoming self-employed ${ }^{3}$.

The estimated equation is of the type:

$$
\operatorname{Self}_{i t+1}=\alpha\left(S S W_{i t+1}^{S E}\left(y_{t+1}\right)-S S W_{i t+1}^{W E}\left(y_{t+1}\right)\right)+\beta X_{i t}+\varepsilon_{i t+1}+v_{t+1}+\mu_{i}
$$

When we study the self-employment rate, i.e. the probability of being selfemployed rather than employed, the equation is estimated on the pooled sample, while, when we focus on the transitions from wage-employment to self-employment and vice versa, we select employees (or, alternatively, the self-employed) and follow them until they switch.

In equation (1) we include the difference between the expected SSW in the event that a worker decides to be self-employed from time $t+1$ onwards $\left(S S W_{i t+1}^{S E}\left(y_{t+1}\right)\right)$ and the expected SSW in the event that he decides to be (wage) employed from time $t+1$ $\left(S S W_{i t+1}^{W E}\left(y_{t+1}\right)\right)$. The past career up to time $\mathrm{t}$ is taken as given. The expected SSW is equal to the present value of benefits expected by the worker minus the payroll tax which has to be paid from time $t+1$ onwards. The income variable $y_{t+1}$ refers to the individual career: the income stream until time $t+1$, and hence the past income stream, is taken as given, and may include both periods in wage-employment and periods in self-employment. Expected real income from time $t+2$ onwards is set equal to income at time $t+1$, and it is assumed to be the same both in the case of self-employment and in the case of wage-employment ${ }^{4}$. Thus, the variation in SSW is due to the different rules in place for self-employed and wage-employed workers, which is what we wish to capture, rather than relating to differences on expected income streams. However, SSW at time $t+1$ depends on the expected income stream based on income at time $t+1$, which is endogenous to the decision to be (or to become) self-employed. Analogously to the tax literature (in particular, Hansson, 2012), we also compute the expected SSW at time $t+1$, using the rules in force in period $t+1$, and an income stream constructed on the knowledge of income up to time $\mathrm{t}$ (which we call $\left(y_{t}\right)$ ), hence assuming real income from time $\mathrm{t}+1$ onwards is constant and equal to time $\mathrm{t}$ income. We also compute this

temporarily), we are unable to know if he is having a spell of work in a scheme not covered by INPS or if he is out of the labour force.

${ }^{3}$ Those studies, however, estimate a transition random effect probit and have to take explicit account of the correlation between the probability of being included in the sample and the individual random effect (resulting in an initial conditions problem). Conversely, our estimation procedure explicitly allows for the individual unobserved effect to be correlated with the observables.

${ }^{4}$ In section 6 we provide a more detailed description of the procedure to compute SSW. 
expected SSW in the two scenarios, those of self-employment and wage work, and use the difference in these two variables as an instrument in equation (1). Alternatively, we also estimate the reduced form of (4), plugging in $\left(S S W_{i t+1}^{S E}\left(y_{t}\right)-S S W_{i t+1}^{W E}\left(y_{t}\right)\right)$ as a regressor in place of the original SSW variables.

The $\mathrm{X}$ variables include age dummies and other variables which may explain the probability of being (or becoming, depending on the specification) self-employed. In particular, we include the present value of real income, which represents the present value, valued at time $t$, of income from work earned throughout the entire working life. This income stream is the same used to construct expected SSW and it is assumed to be the same in the two scenarios. In particular, to avoid endogeneity issues, income up to period $t$ is taken to be the one actually observed for each individual, while from period $\mathrm{t}+1$ onwards, it is assumed to be constant in real terms and equal to income in period $\mathrm{t}$. This value is meant to capture the overall performance in the labour market, reflecting the opportunity cost to become self-employed, or poor employment opportunities. Alternatively, however, it may be the case that high income workers have more opportunities to be successful when they are self-employed, resulting in a positive coefficient. $^{5}$

Additionally, we include other variables capturing the labour market performance up to period t. Total experience is defined as the number of periods a worker has spent in the labour market since entering the labour force. These include working spells as well as periods of sick or subsidised unemployment, both as an employee or as a self-employed worker. In addition, we include the fraction of time since entering the labour force for the first time spent outside the INPS archive, i.e. not working as a covered INPS worker, and not having sick or subsidised unemployment spells. Finally, we also include the fraction of time, since entering the labour force for the first time, spent on sick or subsidised unemployment leave. All these variables are expected to identify whether or not individuals with poor careers are pushed into selfemployment.

In equation 1, we also include a common time effect $\left(v_{t+1}\right)$, an individual-specific time-invariant effect $\left(\mu_{\mathrm{i}}\right)$ and an idiosyncratic shock $\left(\varepsilon_{\mathrm{it}+1}\right)$. We control for individualspecific effects by demeaning.

As is typical in these kinds of studies, we are unable to disentangle age, time and cohort effects. While we estimate a flexible specification including both year and age dummies, we do not attempt to interpret them attributing trends to either component.

${ }^{5}$ In addition, to account for short run macroeconomic effects, i.e. the effect of the business cycle, we experimented with including in the model the cycle component of (log of) GDP per capita at regional level. This variable shows a non-negligible variation in the analysed period. However, it was found that the magnitude of the effect of that variable on the analysed outcomes was very small and we decided to exclude it from our models. 
As our final sample numbers approximately 9.3 million observations, we are also able to estimate the age-specific response of the probability of self-employment to public pension wealth by interacting expected SSW with age dummies.

\section{Data}

We use a sample of administrative data drawn from the archive of the main Italian Social Security scheme (National Institute of Social Security, Istituto Nazionale di Previdenza Sociale, INPS) ${ }^{6}$.

The INPS archive officially records the complete earnings and contribution histories of all participants, i.e. employees in the private sector and some categories of the self-employed (craftsmen, tradesmen and farmers). Other categories of selfemployed workers, and, in particular, professional workers, have their own independent pension funds and are not covered by INPS; hence we have no information on those professional workers. The available sample is formed by all individuals born on the first and the ninth of each month of any year - so that the theoretical sample frequency is 24:365 - and reports employment spells until 2012. The archive contains very rich information about the earnings histories of the workers, recording spells of unemployment and sickness, as well as labour income earned each year.

As is typical with administrative data, the demographic information is, on the other hand, less rich: The sample records the gender, date and region of birth and region of residence in 2012 for each worker. No information about the family status or education level of the worker is available.

We clean our sample in the following way. We start by restricting our attention to the period 1985-2005, as we are interested in studying the effect of reforms to the pension system that occurred during the nineties ${ }^{7}$. We also select male individuals born between 1940 and 1980, as well as workers aged between 25 and $59^{8}$. We also disregard individuals whose information on region of birth is missing, as well as individuals born in a foreign region, for which different pension rules apply ${ }^{9}$.

${ }^{6}$ The file LoSai (Longitudinal Sample Inps) is available on the Italian Ministry of Labour website (http://www.cliclavoro.gov.it/Barometro-Del-Lavoro/Pagine/Microdati-per-la-ricerca.aspx).

${ }^{7}$ However, to compute the expected pension and other measures used in the analysis, we use all information available including all years prior to 1985 .

${ }^{8}$ Self-employment choices of women belonging to the analysed cohorts are likely to have different dynamics to those of males. In particular, women experienced a great secular increase in labour market participation and wages in the analysed period. Including individuals younger than 25 may raise issues of sample selection bias related to education choices.

${ }^{9}$ We do not observe the foreign region of birth in question. 
We transform the data into yearly spells by adding up, for each year, the number of weeks worked and the income earned. If an individual contributed to both wage- and self-employment schemes in the same year, we define the main scheme as the one in which the majority of time was spent (measured in weeks of work). We keep year observations in which the worker is active for at least 12 weeks. Other cut-points produce more or less similar results.

After these selections and transformations we are left with a sample of 10.4 million person-year observations, pertaining to workers contributing to five main schemes: employees, the self-employed, agricultural workers, flexible workers and a remaining group which includes minor schemes such as clergymen or rail workers (which we label "other").

In table 1 we report the transition probabilities for these workers. The table highlights that employees and the self-employed together account for more than 90 per cent of the workers covered by INPS. In general, all categories of workers tend to remain in their scheme, with 97.5 (95.8) per cent of employees (self-employed) in one period remaining in wage(self)-employment in the next. Flexible workers are an exception, as they are typically (but not solely) younger workers who enter the job market with a flexible contract. As this type of contract was only introduced in Italy in 1995, we do not include these workers in our analysis.

Table 1 - Transition probabilities between categories of workers - yearly data

\begin{tabular}{|l|c|c|c|c|c|c|}
\hline & Employee & Self-employed & Agriculture & Flexible & Other & Total \\
\hline Employee & 97.51 & 1.46 & 0.13 & 0.69 & 0.21 & 100 \\
\hline Self-employed & 2.9 & 95.84 & 0.06 & 1.17 & 0.03 & 100 \\
\hline Agriculture & 2.83 & 0.54 & 96.04 & 0.58 & 0.02 & 100 \\
\hline Flexible & 12.43 & 8.42 & 0.61 & 77.94 & 0.59 & 100 \\
\hline Other & 4.3 & 0.24 & 0.01 & 0.88 & 94.57 & 100 \\
\hline Total & 69.26 & 21.82 & 3.05 & 2.53 & 3.34 & 100 \\
\hline
\end{tabular}

Source: Authors' calculations based on INPS data set.

We then restrict our analysis to employees and self-employed workers, who are the focus of this paper. The self-employment rate, defined as the ratio of self-employed workers to the total, which, in our sample, is given by employees plus the selfemployed, is rather stable over time at around 24-25 per cent, as can be seen from Figure 1. 
Figure 1 -Self-employment rate

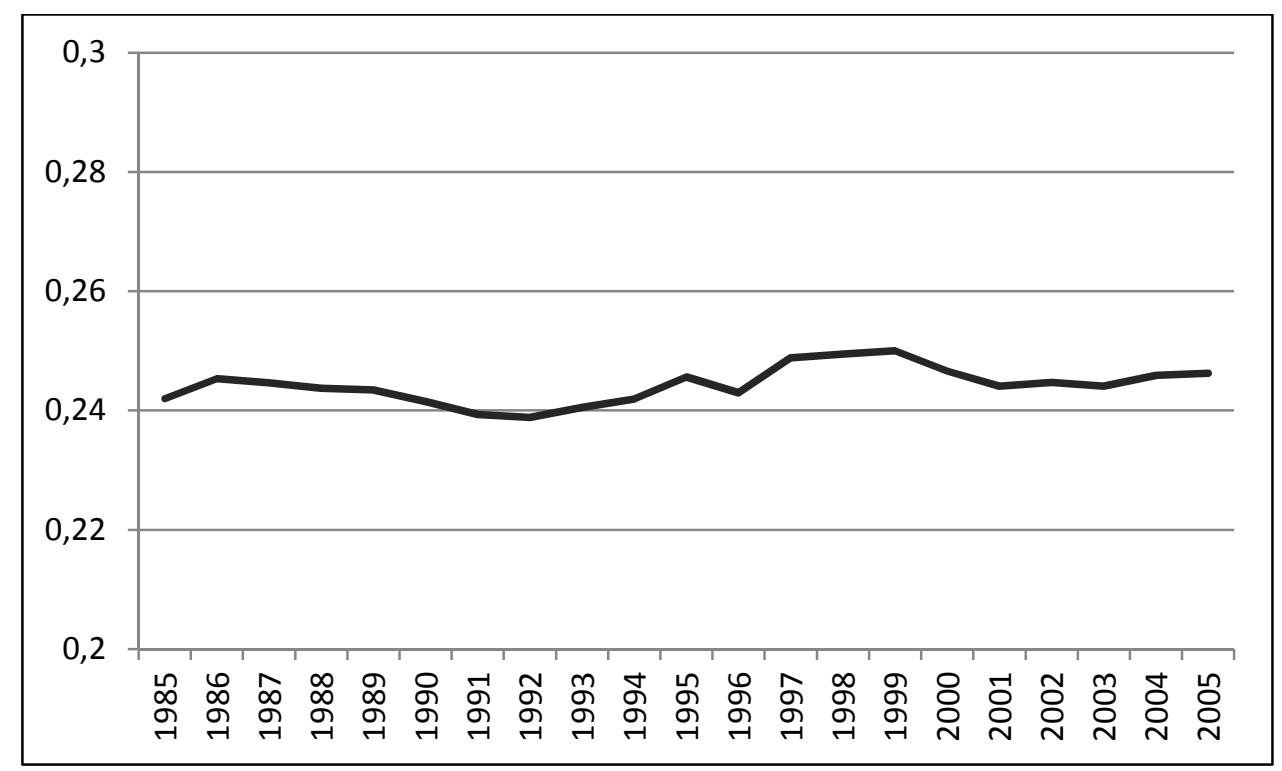

Source: Authors' calculations based on INPS data set.

We then group observations according to year of birth, and form four ten-year year-of-birth groups, born between 1940 and 1980. The time evolution of the selfemployment rate for the resulting four generations (or cohorts) is shown in Figure 2, where, in the x-axis, we report the calendar year to highlight the time effects. For example, in 1985 the self-employment rate of all workers born between 1940 and 1949 (named cohort 1945 in the graph) amounted to 29\%. In the same year, the selfemployment rate for individuals born between 1950 and 1959 (hence aged between 26 and 35 in 1985) amounted to 23\%. Each line in the graph then shows the selfemployment rate of each generation as it ages. The younger generation (born between 1970 and 1980) enters the graph in 1995 as we disregarded individuals younger than 25 from our sample.

Figure 2 shows that the self-employment rate for each cohort slightly increases with age until age 40 - for example, for the 1965 generation, the self-employment rate increases from 20 to $25 \%$ between ages 20 and 40 (i.e. in the 1985-2005 period). For the eldest cohort, born in 1945, the Figure reveals an increase in the self-employment rate after 1995, when the cohort is aged between 45 and 55: this is a result of the fact that many employees start retiring after reaching age 55 while, typically, self-employed workers retire at older ages. 
Figure 2 - Self-employment rate, by cohort

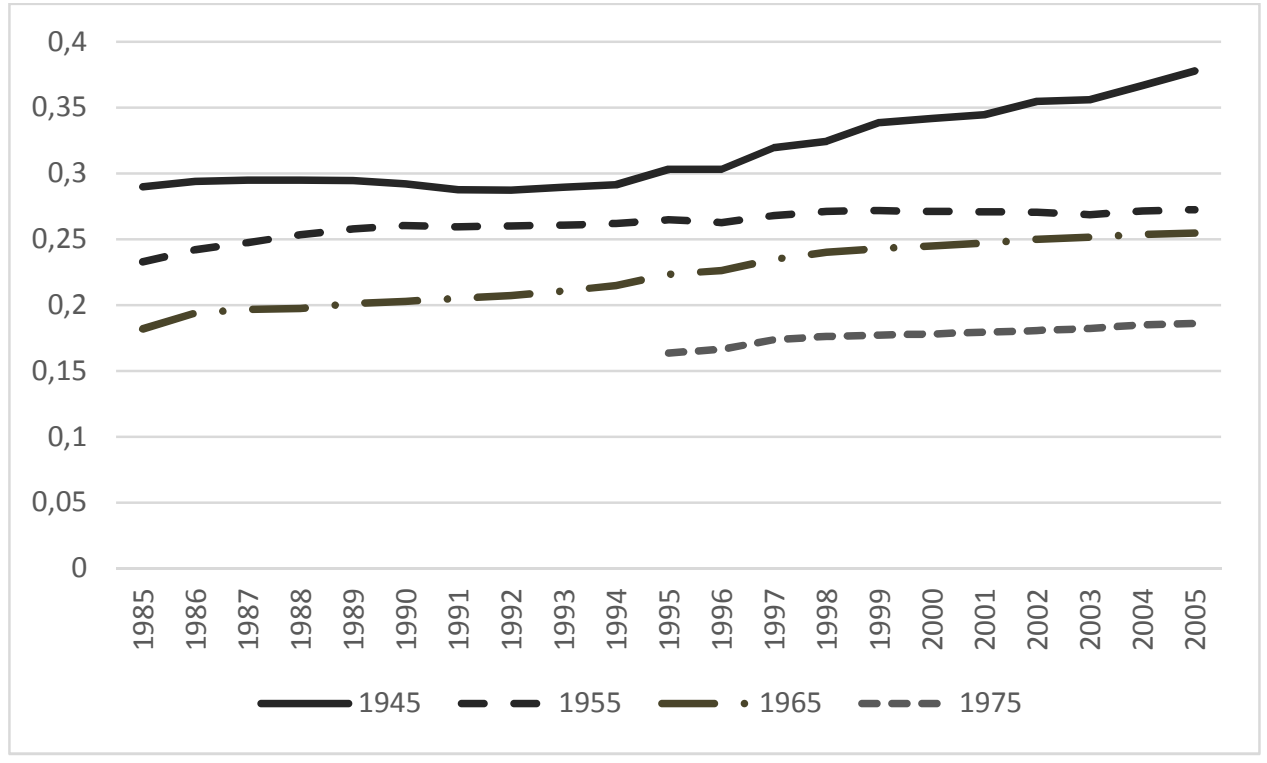

Source: Authors' calculations based on INPS data set.

As we follow the same individuals over time, we are also able to study transitions between employment and self-employment. In table 2, we report the overall transition probabilities for these two groups of workers. As the total number of observations is about 9.3 million, despite the transition from employee to self-employed only occurring with probability of 1.5 per cent, we are able to observe it more than 100,000 times. Self-employed workers, on the other hand, display a higher probability of switching to the employee scheme, of approximately 2.8 per cent (about 66,000 transitions).

Table 2 - Transition probabilities between employees and the self-employed

\begin{tabular}{|l|c|c|c|}
\hline & Employee & Self-employed & Total \\
\hline Employee & 98.53 & 1.47 & 100 \\
\hline Self-employed & 2.84 & 97.16 & 100 \\
\hline Total & 75.13 & 24.87 & 100 \\
\hline
\end{tabular}

Source: Authors' calculations based on INPS data set.

In Figures 3 and 4 below, we show the transitions over time and by cohort. For transitions from employment to self-employment, shown in Figure 3, we select individuals who start their career as employees and follow them until they switch to self-employment (or until the end of the sample if they do not switch). Figure 3 highlights that there are strong cohort effects in the transition rate from employment to self-employment, with younger cohorts being more likely to switch. The age effects are 
also clearly negative, with younger individuals being more likely to switch from employment to self-employment. Common macro shocks are also evident in the figure, such as the spike in the year 1997, a year in which an important reform introducing more flexibility in the labour market was implemented.

Figure 3 - Transition rate from employment to self-employment, by cohort

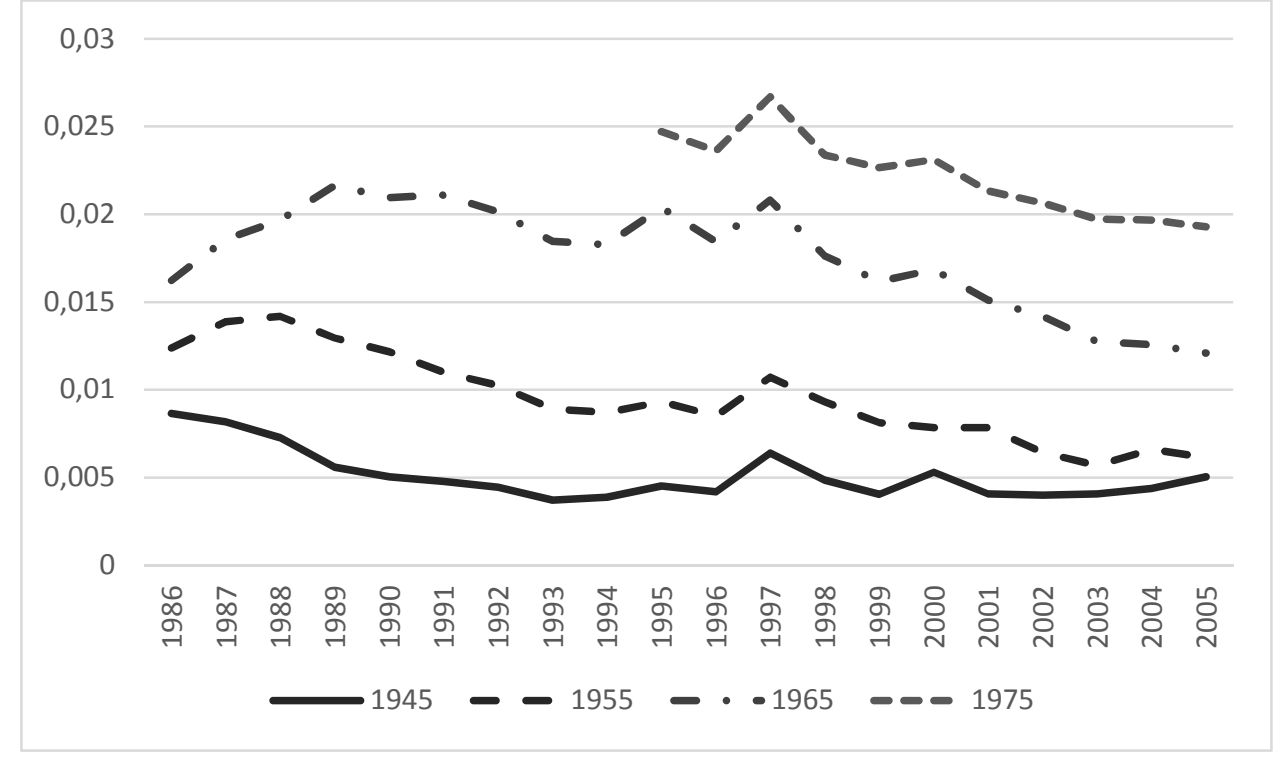

Source: Authors' calculations based on INPS data set.

Similarly, we study transitions from self-employment to employment, selecting individuals who start their career as self-employed and following them until they switch to employment (or until the end of the sample if they do not switch). These transitions are more likely than the previous ones, as already noted in Table 2. Cohort effects are evident in Figure 4, with younger cohorts being more likely to switch. Common time trends can also be spotted: in particular, after 1993 the trend is quite flat for all the cohorts considered. 
Figure 4 - Transition rate from self-employment to employment, by cohort

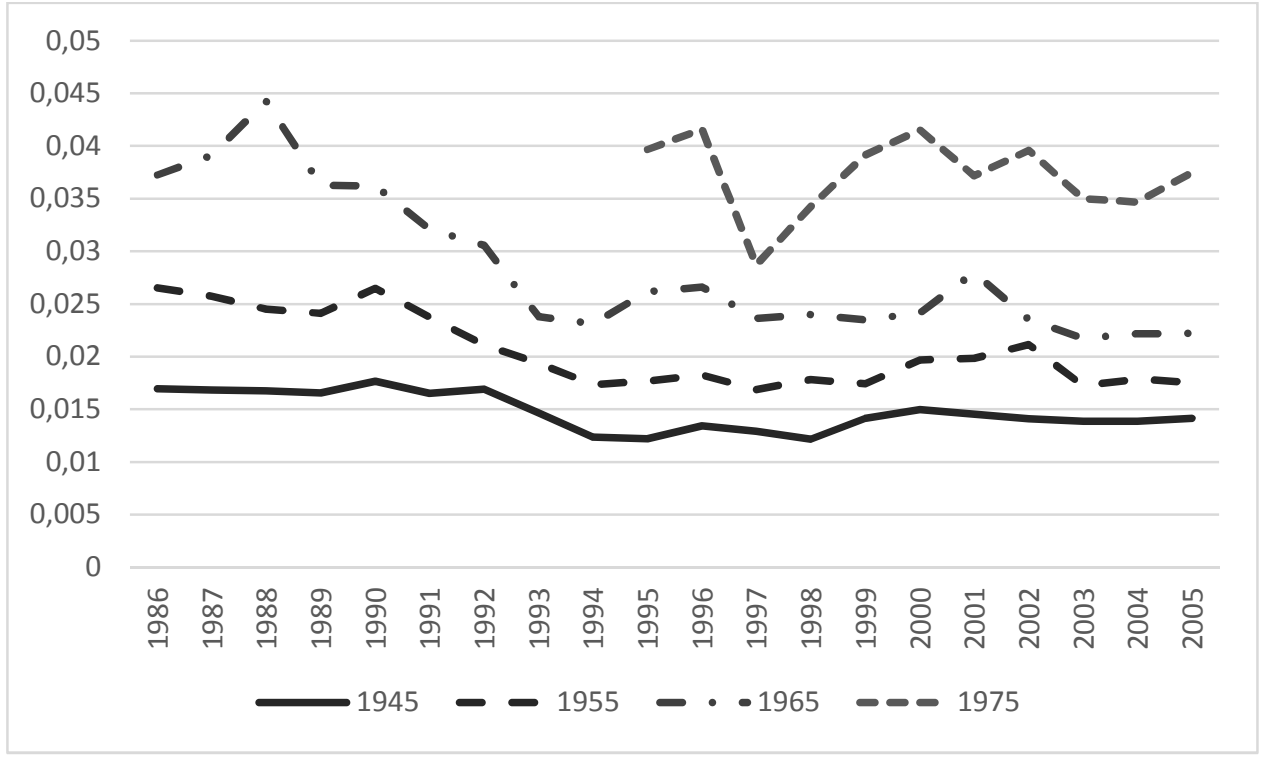

Source: Authors' calculations based on INPS data set.

\section{Results: estimating SSW}

For each selected individual and in each period, we compute his expected Social Security Wealth (SSW) in the two alternative hypotheses of a continuous career, from that point onwards, as an employee or as a self-employed worker, assuming the worker would retire at the legal retirement age applied in each regime. SSW is defined as the present value of benefits expected by the worker minus payroll tax which has to be paid from time $t+1$ onwards. We obtain for each time $t+1$ the relevant quantities in the two alternative scenarios of working as an employee from time $t+1$ to retirement age and of working as a self-employed worker from time $t+1$ to (self-employed) retirement age, taking the past career as given and fixed. In both scenarios, workers (potentially) have mixed careers, as in the past (up to time $t$ ) they may have had spells of employment as well as self-employment.

To obtain the desired quantities, we proceed as follows. We assume the income stream is the same in both scenarios, of employment and self-employment. In this way, variation in SSW depends on the public pension rules and not on our hypotheses about the future evolution of income. In addition, we assume the income stream is given by its actual realisation until time $\mathrm{t}+1$, and it is projected to be constant in real terms from that point onwards, until the worker retires at the legal age required by the legislation in force at time $t+1$. While other hypotheses about the future income stream are certainly possible, we prefer not to introduce a more complicated structure, which may be difficult to interpret. In addition, it should be noted that we are interested in computing 
the difference in SSW when choosing self-employment or employment, and not its level.

Computing the pension benefit and SSW in the case of mixed careers is a complex exercise and we simplify the calculation using a two-step procedure. Using the income stream, constant across scenarios, we start computing the expected pension benefits and contributions paid over the rest of the working life assuming, alternatively, that the individual has been an employee or a self-employed person for all his working life, using the current (at time $t+1$ ) pension legislation. We then approximate the pension benefits in the case of mixed careers according to the actual rules applying in each case. For the scenario of a career as an employee from time $t+1$ onwards, we take a weighted average of the pension benefits in the self-employment and the employment continuous scenarios, using the number of years in each occupation as weights. For the alternative scenario of a career in self-employment from time $t+1$ onwards, the pension benefit is the same as a continuous career in self-employment.

More in detail, for each individual and at each point in time, we compute two estimates of the old-age pension benefits earned at the end of the career, one assuming a full wage employee (WE) career, and the other assuming a full self-employed (SE) career. We compute the Present Value (PV) at time $t+1$ of the discounted sum of the pension benefits received since retirement age until death, and call it $P V_{t+1}\left(P^{W E_{-} c}\right)$ and $P V_{t+1}\left(P^{S E_{-} c}\right)$ respectively. ${ }^{10}$ Similarly, we compute the PV of the contributions to be paid from time $t+1$ until retirement in each employment scenario, $P V_{t+1}\left(C^{W E}\right)$ and $P V_{t+1}\left(C^{S E}\right) .{ }^{11}$ What we need for our estimates are the expected SSWs computed on the basis of the actual career until time $t+1$, and of a projected career of (continuous) wage or self-employment from time $\mathrm{t}+1$ onwards.

According to Italian legislation, a worker could switch from employment to selfemployment at no cost, as the amount of contributions paid was higher in the former case. Hence the expected SSW when continuously being self-employed or when switching to self-employment is the same:

$$
S S W_{t+1}^{S E}=S S W_{t+1}^{S E_{-} c}=P V_{t+1}\left(P^{S E_{-} c}\right)-P V_{t+1}\left(C^{S E}\right)
$$

Where $S S W_{t+1}^{S E}$ is SSW computed at time $\mathrm{t}+1$ in the case of a mixed career, while $S S W_{t+1}^{S E_{-} c}$ is SSW in the case of a full SE career.

${ }^{10}$ WE_c indicates a complete career as wage-employed while SE_c indicates a complete career as self-employed. The discount factor used to compute the PV includes the survival probability and a real discount rate equal to $1.5 \%$.

${ }^{11}$ For comparability with the self-employment case, for employees we consider the total amount of contributions, paid by the worker and by the employer, from time $\mathrm{t}+1$ onwards. 
When computing the opposite case, that of a worker in wage-employment from time $t+1$ onwards, we need to consider that for workers switching from selfemployment to employment the transition was (and still is) costly. We approximate the expected SSW in this case as the weighted average of the PV of the pension benefits based on the continuous careers, using as weights the number of periods spent in each occupation, minus the PV of the contributions still to be paid:

$$
S S W_{t+1}^{W E}=\frac{N_{w e}}{N_{\text {TOTwe }}} P V_{t+1}\left(P^{W E_{-} c}\right)+\frac{N_{S e}}{N_{\text {TOTwe }}} P V_{t+1}\left(P^{S E_{-} c}\right)-P V_{t+1}\left(C^{W E}\right)
$$

Where $\mathrm{N}_{\mathrm{we}}$ is the number of years a worker spent contributing to the employee scheme throughout his working life, $\mathrm{N}_{\mathrm{se}}$ is the number of years spent contributing to the self-employed scheme, and $\mathrm{N}_{\text {TOTwe }}$ is the total number of years spent in the labour market when retiring as a wage employee. The career length is individual-specific as we observe the entrance into the labour market for each individual. Formula (3) applies with the condition of accruing at least 15 years of contributions in each scheme. If a worker accrues less than 15 years in a scheme, which was the minimum seniority required to claim a retirement benefit in the years considered in our study, he is not entitled to obtain a benefit in that scheme and his pension will only be constituted by the benefit accrued in the other scheme ${ }^{12}$.

For illustrative purposes, in Figures 5 and 6 we show the average SSW in the continuous scenarios $\left(\left(S S W_{t+1}^{W E_{-} c}\right.\right.$ and $\left.S S W_{t+1}^{S E_{-} c}\right)$, i.e. assuming continuous careers either as employed or as self-employed, by ten years-of-birth generations (from 1940 to 1980). As occurred previously, the variable of interest is plotted with the calendar year on the $\mathrm{x}$-axis, in order to highlight the macro shocks induced by the reforms. When all other aspects are equal, SSW is lower for younger individuals whose distance from retirement age is greater (as contributions have to be paid for a longer period; in addition, there is a discounting effect). Starting with SSW where an individual remains an employee for his whole life, shown in Figure 5, the effects of the 1992 and 1995 reforms can clearly be seen for each cohort: younger cohorts start with a lower SSW both because in any year they are younger and because the payroll tax rate increased quite steadily over time, well before the nineties. Our results on the effect of the reforms are in line with those found, for example, by Borella and Coda Moscarola (2006, 2011).

The SSW where an individual is always self-employed is shown in Figure 6. Self-employed workers before 1990 paid lower (although increasing over time) payroll tax rates and received, on average, lower benefits, computed with a DC mechanism. Their expected SSW is consequently lower than that of employees until the reform of 1990. That reform, increasing both the contributions and benefits for the self-employed, resulted in an increase in their SSW starting from the years 1990-91. Subsequently, the

\footnotetext{
${ }^{12}$ In other words, we are assuming that it is not possible to reunite contributions and seniority, as in reality this was (and still is) extremely expensive.
} 
self-employed were also hit by the reforms in 1992 and 1995, which had the effect of reducing their expected SSW, although to a lesser extent than employees.

Figure 5 - Average Social Security Wealth in the case of a career in wage-employment

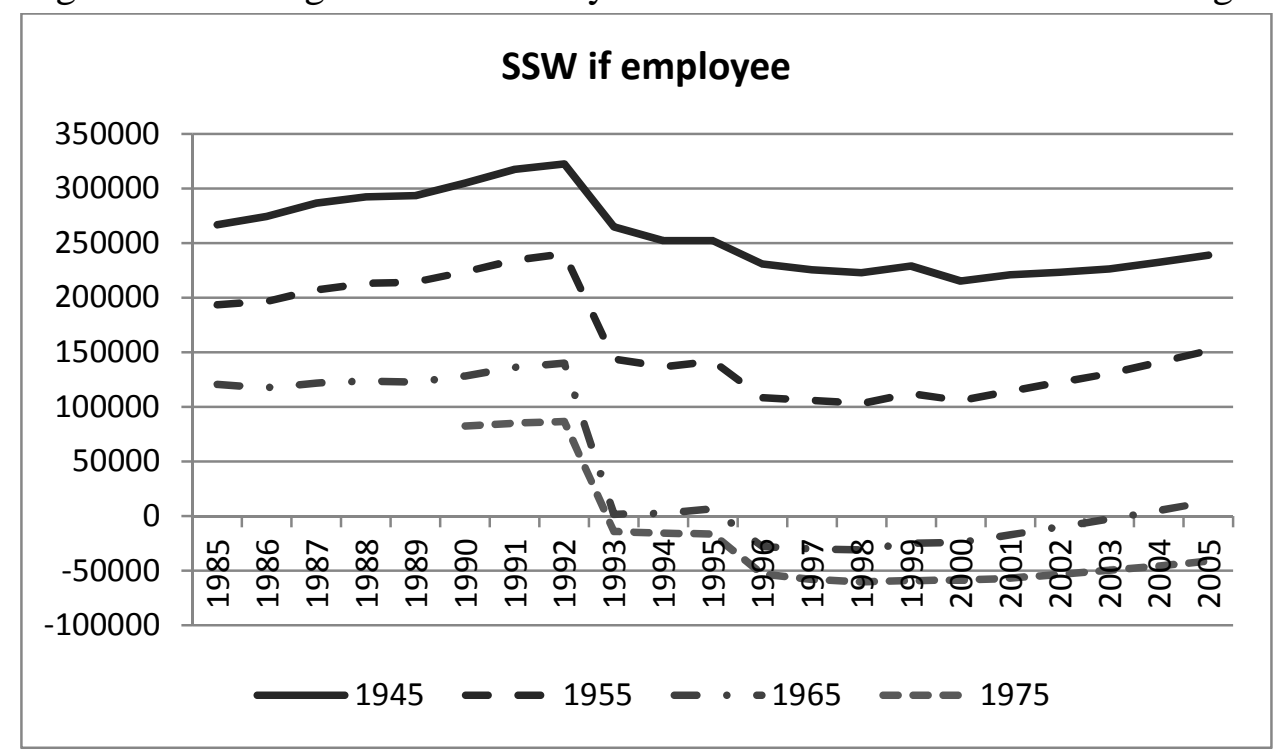

Note: values expressed in 2013 Euro. Source: Authors' calculations.

Figure 6 - Average Social Security Wealth in the case of a career in self-employment

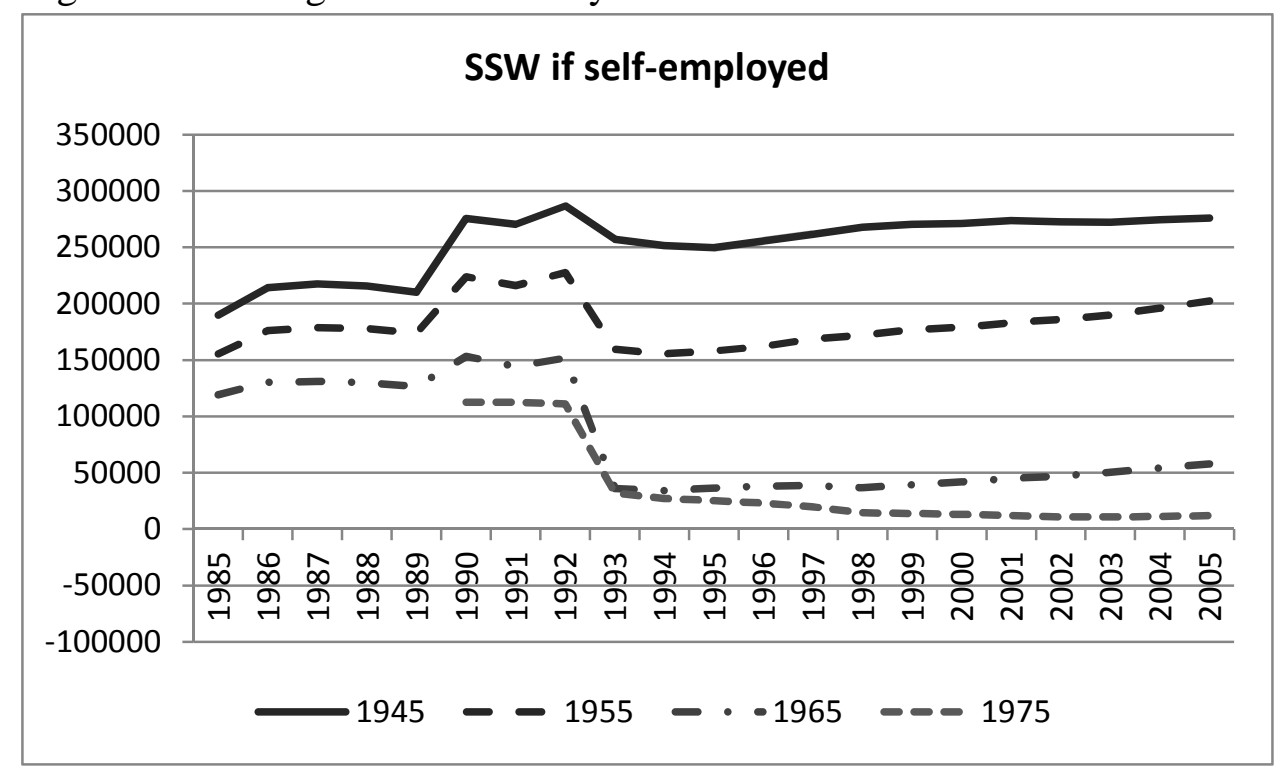

Note: values expressed in 2013 Euro. Source: Authors' calculations. 
Our main variable of interest is not SSW itself but, rather, the difference in SSW deriving from opting to be in self-employment or employment from time $t+1$ onwards, given the career undertaken until that time: $S S W_{i t+1}^{S E}\left(y_{t+1}\right)-S S W_{i t+1}^{W E}\left(y_{t+1}\right)$ in terms of equation (1). The evolution of this variable by cohort and over time is shown in Figure 7. The Figure shows that this difference varies greatly across generations and over time. For example, for workers born in 1945 the average difference moves from around 40,000 Euro in 1985 to almost 60,000 Euro in the year 2000. The difference, on average, was negative until 1990, i.e. until the first reform that increased the SSW for the self-employed, and positive thereafter, indicating that after the reforms of the 1990s the self-employed have a higher SSW than employees. In addition, after the year 2000, the difference diminishes for all cohorts and the variation across cohorts also vanishes, a result of the (slow) harmonisation process introduced by the reforms.

Figure 7 - Average difference in SSW in the case of self-employment or employment, by cohort

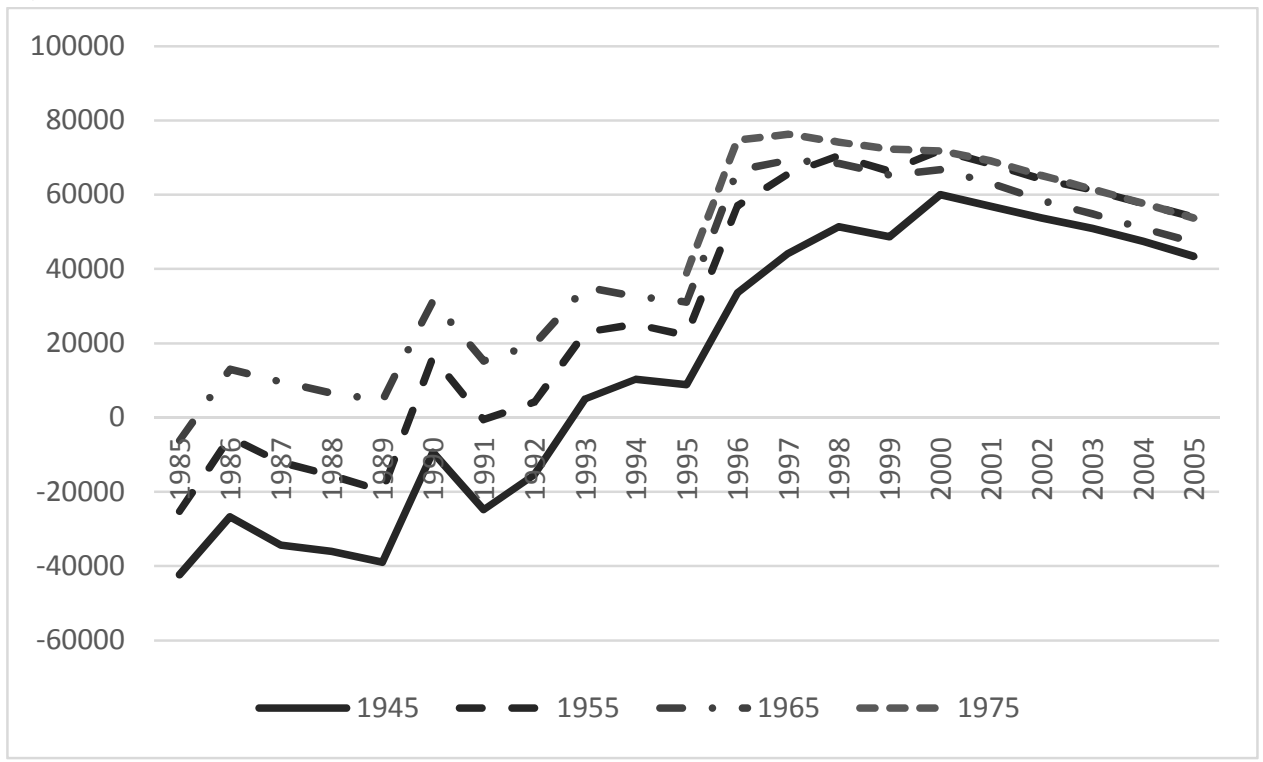

Note: values expressed in 2013 Euro. Source: Authors' calculations.

\section{Results: self-employment status}

We estimate the effect of SSW on the probability of an individual being selfemployed rather than wage-employed for individuals who were either self-employed or wage employed between 1985 and 2005. In all our specifications we include the difference between the expected SSW for the case where the worker decides to be selfemployed for the rest of his working life and the expected SSW for the case where he chooses to be an employee from the current period onwards until retirement. As discussed earlier, we estimate expected SSW using the rules in force at $t+1$ and income for the same period, as well as expected SSW using $\mathrm{t}+1$ rules and income in period $\mathrm{t}$. 
We use this second couple of variables (in the case of self-employment and wageemployment) to form an instrument to be used in our main specification and we also estimate the reduced form using the instrument directly as a regressor. The three specifications are shown in table 3 , columns 1 to 3 .

In the first column we find that the overall coefficient for the difference in SSW ${ }_{t+1}\left(\mathrm{y}_{\mathrm{t}+1}\right)$ where an individual chooses self-employment versus wage-employment amounts to 0.42 , with a standard error of 0.004 , hence statistically different from zero at any standard significance level. As our sample consists of about 9.3 million person-year observations, estimating very low standard errors - or, in other words, estimating coefficients with small confidence intervals - is unsurprising. What is important in this context is the size of the effect, as we are, in principle, able to estimate precisely effects that are close to zero. As our SSW variables are expressed in millions, our finding implies that, other things being equal, a 10,000 Euro increase in the difference in SSW increases the probability of being in self-employment by about 0.42 percentage points. The average increase in the difference in SSW both between 1989 and 1990 and between 1995 and 1996 was approximately 30,000 Euro in each case. Assuming that these differences are due entirely to the change in Social Security rules, our estimate implies that the effect of these two reforms on the probability of being in selfemployment was of 1.26 percentage points. The 1992 reform had, on average, a lesser effect on the difference in expected SSW, of about 20,000 Euros, implying an increase in the probability of being in self-employment of about 0.84 percentage points.

As a measure of the overall performance in the labour market, we also include the present value of income, computed assuming real income is a random walk, hence its predicted value from time $t+1$ to retirement is equal to real income at time $t$. The income stream is assumed to be the same under the two scenarios of self-employment and wage-employment. We find a small, negative effect of this variable: a 10,000 Euro increase in the PV of income reduces the probability of being self-employed by 0.1 percentage points. In addition, we find that labour market experience, measured in years, increases the probability of being self-employed by about 0.7 percentage points for every additional year. Individuals who have been in the labour market for longer are more likely to have switched to self-employment, as already found, for example, by Evans and Leighton (1989).

We also find that the fraction of time spent out of the labour force increases the probability of being self-employed, indicating that individuals with poor career prospects may be pushed into self-employment. Conversely, the fraction of time spent in sick or subsidised unemployment leave - two benefits typically (but not solely) received by wage-employed workers - reduces the probability of being self-employed, indicating that workers who are protected are less likely to be self-employed. 
In column 2 we estimate the same specification with an FE-2SLS estimator, using as instrument the difference in expected SSW in the case of self-employment and wage-employment computed on an expected income stream based on past income up to time t. The coefficient estimated from the first stage is reported in the bottom part of the table and amounts to 0.72 , indicating that our instrument indeed helps to explain the difference in SSW. This estimate confirms the results shown in column 1, with the absolute values of the coefficients on the difference in expected SSW higher than the one found in the first column, as a 10,000 Euro increase in the difference raises the probability of being self-employed by about 0.7 percentage points.

Finally, in the third column we report the reduced form estimates, with the expected SSW in the case of self-employment and wage-employment computed on an expected income stream based upon past income up to time t included as regressors. The results indicate that with a 10,000 Euro increase in the difference, this raises the probability of being self-employed by 0.5 percentage points.

Table 3 - The effect of the difference in SSW on the self-employment rate

\begin{tabular}{|c|c|c|c|}
\hline & $\begin{array}{l}\mathrm{FE} \\
\mathrm{b} / \mathrm{se}\end{array}$ & $\begin{array}{c}\text { FE-2SLS } \\
\mathrm{b} / \mathrm{se}\end{array}$ & $\begin{array}{c}\text { FE-RF } \\
\text { b/se }\end{array}$ \\
\hline$S S W_{i t+1}^{S E}\left(y_{t+1}\right)-S S W_{i t+1}^{W E}\left(y_{t+1}\right)$ & $\begin{array}{c}0.4181 * * * \\
(0.0036)\end{array}$ & $\begin{array}{c}0.6953 * * * \\
(0.0026)\end{array}$ & \\
\hline$S S W_{i t+1}^{S E}\left(y_{t}\right)-S S W_{i t+1}^{W E}\left(y_{t}\right)$ & & & $\begin{array}{c}0.5119^{* * *} \\
(0.0041)\end{array}$ \\
\hline$P V(Y)_{t}$ & $\begin{array}{c}-0.0991 * * * \\
(0.0009)\end{array}$ & $\begin{array}{c}-0.1111 * * * \\
(0.0004)\end{array}$ & $\begin{array}{c}-0.0969^{* * * *} \\
(0.0009)\end{array}$ \\
\hline Experience & $\begin{array}{c}0.0068 * * * \\
(0.0004)\end{array}$ & $\begin{array}{c}0.0052 * * * \\
(0.0001)\end{array}$ & $\begin{array}{c}0.0067 * * * \\
(0.0004)\end{array}$ \\
\hline Out of work & $\begin{array}{l}0.0077 * * \\
(0.0038)\end{array}$ & $\begin{array}{c}0.0166 * * * \\
(0.0014)\end{array}$ & $\begin{array}{c}0.0190 * * * \\
(0.0038)\end{array}$ \\
\hline Sick or unemployed & $\begin{array}{c}-0.1549 * * * \\
(0.0028)\end{array}$ & $\begin{array}{c}-0.1524 * * * \\
(0.0016)\end{array}$ & $\begin{array}{c}-0.1557 * * * \\
(0.0028)\end{array}$ \\
\hline Constant & $\begin{array}{c}0.2268 * * * \\
(0.0027)\end{array}$ & $\begin{array}{c}0.2545 * * * \\
(0.0009)\end{array}$ & $\begin{array}{c}0.2241 * * * \\
(0.0027)\end{array}$ \\
\hline $\begin{array}{l}\text { First stage: } \\
S S W_{i t+1}^{S E}\left(y_{t}\right)-S S W_{i t+1}^{W E}\left(y_{t}\right)\end{array}$ & & $\begin{array}{c}0.7192 * * * \\
(0.0003)\end{array}$ & \\
\hline $\begin{array}{l}\text { Number of observations } \\
\text { R-squared within }\end{array}$ & $\begin{array}{c}9,288,651 \\
0.025\end{array}$ & $\begin{array}{c}9,288,651 \\
0.022\end{array}$ & $\begin{array}{c}9,288,651 \\
0.026\end{array}$ \\
\hline
\end{tabular}


Notes: the dependent variable is equal to 0 in the case of employment and to 1 in the case of selfemployment. FE: fixed-effects estimate. FE-2SLS: fixed-effects two-stage least-squares estimate. FE-RF: fixed effects reduced form estimate. Clustered standard errors in parentheses. All specifications include time and age dummies. The SSW variables and the PV of income are all expressed in millions at 2013 prices. Significance levels: $* \mathrm{p}<0.1, * * \mathrm{p}<0.05, * * * \mathrm{p}<0.01$.

Finally, we relax the assumption that the effect of the difference in SSW is constant over age and estimate a fully flexible model where the difference in SSW is interacted with age dummies. Thanks to the very large sample size at our disposal, the parameters are very precisely estimated (the results are available upon request). Figure 7 reports the resulting average marginal effects (including 95 per cent confidence intervals) by age for the difference in $\mathrm{SSW}_{t+1}\left(\mathrm{y}_{t}\right)$, estimated using the reduced form specification to avoid endogeneity issues ${ }^{13}$.

The effect of the difference in SSW on the probability of being self-employed decreases with age up to age 45, and increases again at older ages. As the difference in SSW is measured in millions, the findings shown in figure 4 indicate, for instance, that a 10,000 Euro increase in the difference in SSW determines an increase in the probability of being self-employed of about 1 percentage point at age 27 and of 0.4 percentage points at age 45 .

13 In addition, with respect to the 2SLS-FE estimates, we keep the computing time at a reasonable level. 
Figure 7 - Average marginal effect of the difference in SSW, by age, on the selfemployment rate.

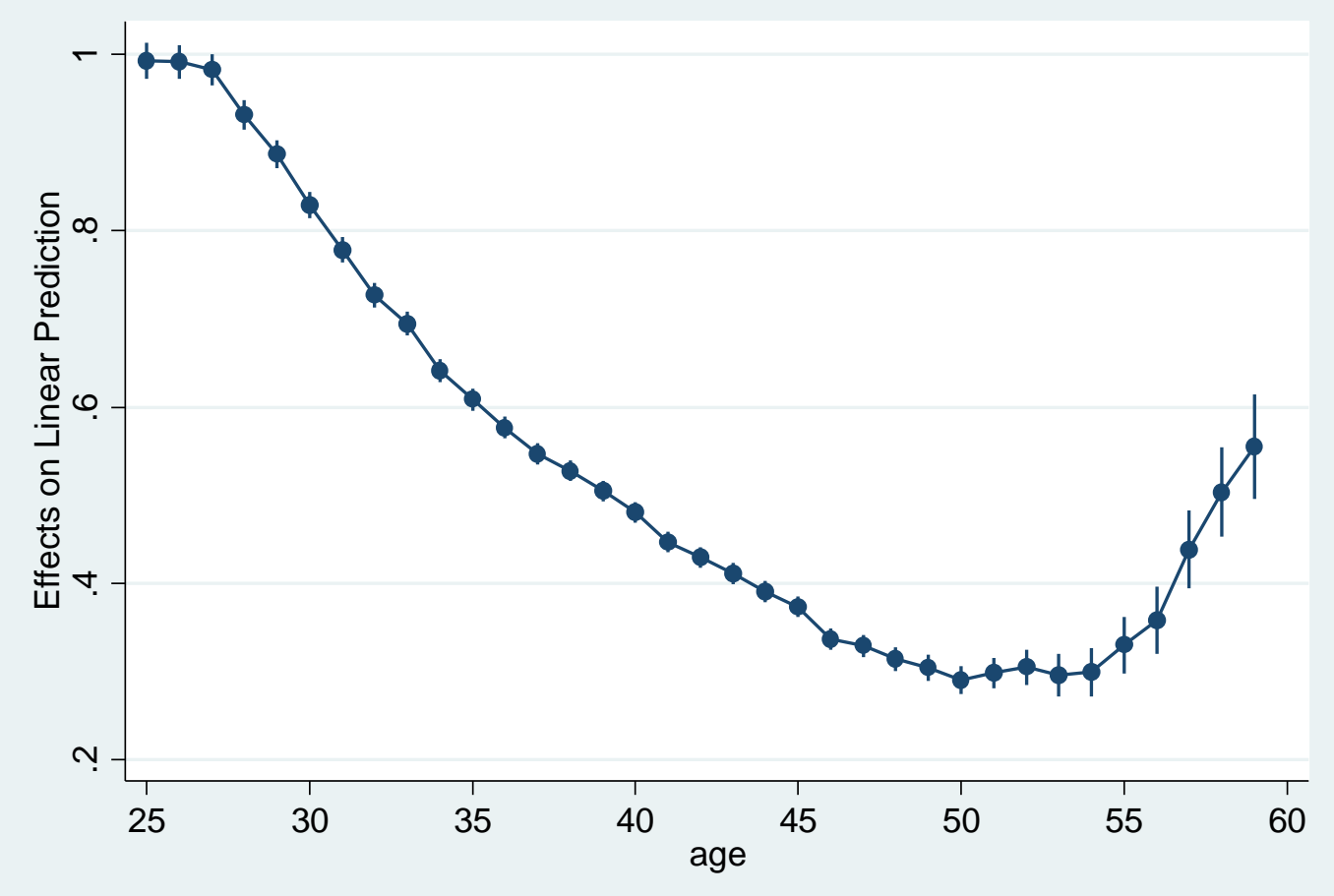

Source: Authors' calculations.

\section{Results: transitions to self-employment}

In table 4 we show the estimates of the probability of switching to selfemployment. To obtain these estimates, we select wage-employed individuals and include them in the sample until they switch to self-employment. If they do switch, subsequent observations are disregarded from the sample.

Also in this case we estimate three specifications: our basic fixed-effect specification, an FE-2SLS specification to account for endogeneity in expected SSW, and the reduced form.

The results, consistent with our previous estimates of the self-employment rate, indicate that an increase in the difference in expected SSW increases the probability of switching to self-employment from wage-employment. The estimate of this effect is equal to about 0.15 percentage points every 10,000 additional Euros in the difference in SSW for specification 1, again to about 0.15 percentage points in the FE-2SLS estimates, and finally to 0.1 percentage points in the reduced form reported in column 3 . As the probability of switching is very low (as shown in section 5) and equal to $1.3 \%$ on average, the effect of the difference in expected SSW is quite sizeable even in the latter estimate. The average increase in the difference in SSW both between 1989 and 1990 
and between 1995 and 1996 was of about 30,000 Euro, while between 1992 and 1993 the average increase was of about 20,000. Our 2SLS-FE estimate implies that the effect of the 1990 and 1995 reforms on the probability of switching to self-employment were of 0.45 percentage points after the 1990 and 1995 reforms and of almost 0.30 percentage points after the 1992 reform.

The present value of the income stream has a negative effect on the probability of switching; indicating a 100,000 Euro increase in this variable reduces the probability of entering self-employment by 0.6 percentage points - a result that provides some evidence in favour of the 'push' hypothesis.

Experience in this case measures the number of years spent in the labour market as wage-employed and it has a negative effect on the probability of switching: ten additional years spent in the labour market as an employee reduce the probability of switching by 1 per cent. The fraction of time spent out of the INPS archive has a positive impact on the probability of switching, while the fraction of time spent in sick or subsidised unemployment has a negative effect, consistently with what we found for the self-employment rate in the previous section. 
Table 4 - The effect of the difference in SSW on the transition rate from WE to SE

\begin{tabular}{|c|c|c|c|}
\hline & $\begin{array}{l}\text { FE } \\
b / s e\end{array}$ & $\begin{array}{l}\text { 2SLS-FE } \\
\mathrm{b} / \mathrm{se}\end{array}$ & $\begin{array}{l}\text { RF-FE } \\
\text { b/se }\end{array}$ \\
\hline$S S W_{i t+1}^{S E}\left(y_{t+1}\right)-S S W_{i t+1}^{W E}\left(y_{t+1}\right)$ & $\begin{array}{l}0.1465 * * * \\
(0.0020)\end{array}$ & $\begin{array}{l}0.1460 * * * \\
(0.0021)\end{array}$ & \\
\hline$S S W_{i t+1}^{S E}\left(y_{t}\right)-S S W_{i t+1}^{W E}\left(y_{t}\right)$ & & & $\begin{array}{l}0.0961^{* * *} \\
(0.0020)\end{array}$ \\
\hline $\mathrm{PV}(\mathrm{Y})_{\mathrm{t}}$ & $\begin{array}{l}-0.0600 * * * \\
(0.0006)\end{array}$ & $\begin{array}{l}-0.0600 * * * \\
(0.0003)\end{array}$ & $\begin{array}{l}-0.0563 * * * \\
(0.0006)\end{array}$ \\
\hline Experience & $\begin{array}{l}-0.0107 * * * \\
(0.0002)\end{array}$ & $\begin{array}{l}-0.0107 * * * \\
(0.0001)\end{array}$ & $\begin{array}{l}-0.0102 * * * \\
(0.0002)\end{array}$ \\
\hline Out of work & $\begin{array}{l}0.0251^{* * *} \\
(0.0016)\end{array}$ & $\begin{array}{l}0.0252 * * * \\
(0.0009)\end{array}$ & $\begin{array}{l}0.0349 * * * \\
(0.0016)\end{array}$ \\
\hline Sick or unemployed & $\begin{array}{l}-0.0217^{* * * *} \\
(0.0009)\end{array}$ & $\begin{array}{l}-0.0217 * * * \\
(0.0009)\end{array}$ & $\begin{array}{l}-0.0241^{* * *} \\
(0.0009)\end{array}$ \\
\hline Constant & $\begin{array}{l}0.0640 * * * \\
(0.0014)\end{array}$ & $\begin{array}{l}0.0640 * * * \\
(0.0007)\end{array}$ & $\begin{array}{l}0.0544 * * * \\
(0.0014)\end{array}$ \\
\hline $\begin{array}{l}\text { First stage: } \\
S S W_{i t+1}^{S E}\left(y_{t}\right)-S S W_{i t+1}^{W E}\left(y_{t}\right)\end{array}$ & & $\begin{array}{l}0.6582 * * * \\
(0.0004)\end{array}$ & \\
\hline $\begin{array}{l}\text { Number of observations } \\
\text { R-squared }\end{array}$ & $\begin{array}{l}6,617,088 \\
0.036\end{array}$ & $\begin{array}{l}6,617,088 \\
0.036\end{array}$ & $\begin{array}{l}6617088 \\
0.034\end{array}$ \\
\hline
\end{tabular}

Notes: the dependent variable is equal to 0 in the case of employment and to 1 in the case of selfemployment. FE: fixed-effects estimate. FE-2SLS: fixed-effects two-stage least-squares estimate. FE-RF: fixed effects reduced form estimate. Clustered standard errors in parentheses. All specifications include time and age dummies. The SSW variables and the PV of income are all expressed in millions at 2013 prices. Significance levels: $* \mathrm{p}<0.1, * * \mathrm{p}<0.05, * * * \mathrm{p}<0.01$.

In Figure 8 we show how the effect of the difference in SSW varies with age. The effect is not constant over the age range but it is higher at younger ages, reaching a minimum at 40, and then increasing again thereafter. After that age, the difference in expected SSW is found to play an increasingly important role. After age 55 the sample size reduces, as some employees retire from the labour market, and the standard errors are higher. 
Figure 8 - Average marginal effect of the difference in SSW, by age, on transitions from employment to self-employment.

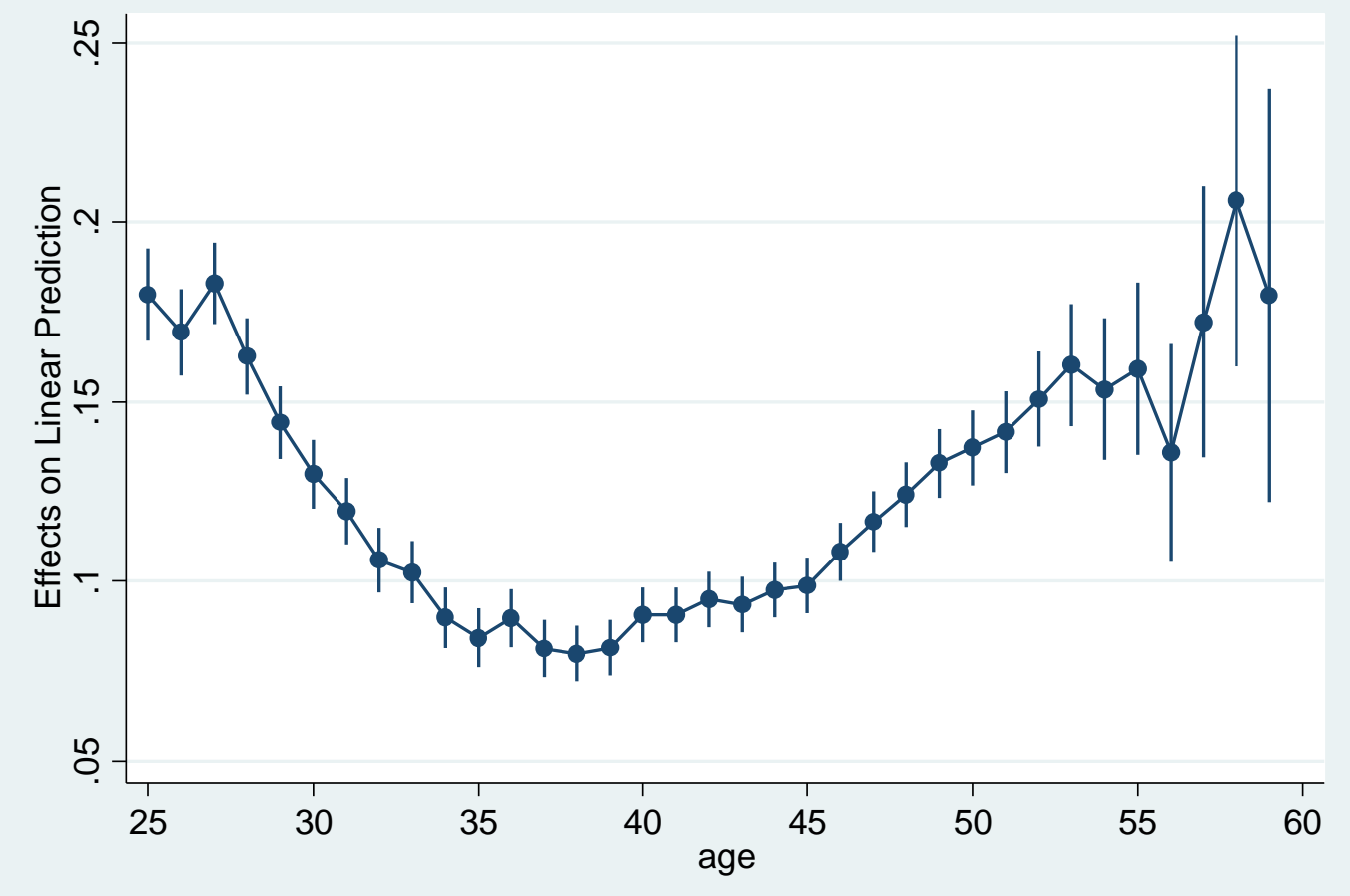

Source: Authors' calculations.

\section{Results: transitions to employment}

As we have a large sample, we are also able to provide evidence on the probability of self-employment workers switching to wage-employment. To this end, we use the same variables and specifications used in the previous sections but this time we define the dependent variable to be equal to 0 when a worker is self-employed, and equal to 1 when he switches to wage-employment. Paralleling the analysis of the previous section, we disregard all observations following the (possible) switch. The results reported in Table 5 show that the effect of the difference in SSW on the probability of switching is quite sizeable: the results from the 2SLS-FE specification reported in the second column imply that a 10,000 Euro increase in the difference in SSW reduces the probability of switching to wage-employment by 0.2 percentage points, while the results from the reduced form in column 3 imply a reduction in the same probability by 0.14 percentage points. The effect of the reforms, implied by our 2SLS-FE estimates and computed as in the previous sections, leads to a reduction in the transition rate of about 0.6 percentage points after the 1990 and 1995 reforms, and of about 0.4 percentage points after the 1992 reform (where the overall transition rate is $2.8 \%)$. 
Also in this case, the present value of income has a negative coefficient, indicating that, conditional upon being a self-employed worker, having a higher income reduces the probability of switching. In other words, successful workers tend not to change job. Experience, measured as years spent as a self-employed worker, also has a negative effect, while experiencing a high fraction of time out of work increases the probability of switching. Self-employed workers who paid contributions while off sick are much more likely to switch to employment.

Table 5 - The effect of the difference in SSW on the transition rate from SE to WE

\begin{tabular}{|c|c|c|c|}
\hline & $\begin{array}{l}\mathrm{FE} \\
\mathrm{b} / \mathrm{se}\end{array}$ & $\begin{array}{l}\text { 2SLS-FE } \\
\mathrm{b} / \mathrm{se}\end{array}$ & $\begin{array}{l}\text { RF-FE } \\
\text { b/se }\end{array}$ \\
\hline$S S W_{i t+1}^{S E}\left(y_{t+1}\right)-S S W_{i t+1}^{W E}\left(y_{t+1}\right)$ & $\begin{array}{l}-0.0935 * * * \\
(0.0037)\end{array}$ & $\begin{array}{l}-0.1984 * * * \\
(0.0050)\end{array}$ & \\
\hline$S S W_{i t+1}^{S E}\left(y_{t}\right)-S S W_{i t+1}^{W E}\left(y_{t}\right)$ & 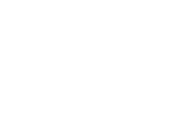 & & $\begin{array}{l}-0.1353^{* * *} \\
(0.0041)\end{array}$ \\
\hline $\mathrm{PV}(\mathrm{Y})_{\mathrm{t}}$ & $\begin{array}{l}-0.0389 * * * \\
(0.0009)\end{array}$ & $\begin{array}{l}-0.0333 * * * \\
(0.0006)\end{array}$ & $\begin{array}{l}-0.0387^{* * *} \\
(0.0009)\end{array}$ \\
\hline Experience & $\begin{array}{l}-0.0334 * * * \\
(0.0006)\end{array}$ & $\begin{array}{l}-0.0335 * * * \\
(0.0002)\end{array}$ & $\begin{array}{l}-0.0334 * * * \\
(0.0006)\end{array}$ \\
\hline Out of work & $\begin{array}{l}0.0874 * * * \\
(0.0046)\end{array}$ & $\begin{array}{l}0.0916^{* * * *} \\
(0.0025)\end{array}$ & $\begin{array}{l}0.0849 * * * \\
(0.0046)\end{array}$ \\
\hline Sick or unemployed & $\begin{array}{l}0.2639 * * * \\
(0.0170)\end{array}$ & $\begin{array}{l}0.2593 * * * \\
(0.0092)\end{array}$ & $\begin{array}{l}0.2637 * * * \\
(0.0170)\end{array}$ \\
\hline Constant & $\begin{array}{l}0.0777 * * * \\
(0.0034)\end{array}$ & $\begin{array}{l}0.0794 * * * \\
(0.0015)\end{array}$ & $\begin{array}{l}0.0797 * * * \\
(0.0034)\end{array}$ \\
\hline $\begin{array}{l}\text { First stage: } \\
S S W_{i t+1}^{S E}\left(y_{t}\right)-S S W_{i t+1}^{W E}\left(y_{t}\right)\end{array}$ & & $\begin{array}{l}0.6820 * * * \\
(0.0007)\end{array}$ & \\
\hline $\begin{array}{l}\text { Number of observations } \\
\text { R-squared }\end{array}$ & $\begin{array}{l}1,782,640 \\
0.071\end{array}$ & $\begin{array}{l}1,782,640 \\
0.070\end{array}$ & $\begin{array}{l}1,782,640 \\
0.071\end{array}$ \\
\hline
\end{tabular}

Notes: the dependent variable is equal to 1 in the case of employment and to 0 in the case of selfemployment. FE: fixed-effects estimate. FE-2SLS: fixed-effects two-stage least-squares estimate. FE-RF: fixed effects reduced form estimate. Clustered standard errors in parentheses. All specifications include time and age dummies. The SSW variables and the PV of income are all expressed in millions at 2013 prices. Significance levels: $* \mathrm{p}<0.1, * * \mathrm{p}<0.05, * * * \mathrm{p}<0.01$. 
Looking at the effect over age ranges, we find a different dynamic, with workers switching from self-employment to employment mostly responsive to the difference in expected SSW at younger ages. While the effect diminishes after age 35, it is still quantitatively very important until age 58. For example, at age 35 a 10,000 Euro increase in the difference in SSW reduces the probability of switching by about 0.2 percentage points, while the same amount at age 46 reduces the probability by 0.1 percentage points.

Figure 9 - Average marginal effect of the difference in SSW, by age, on transitions from self-employment to employment.

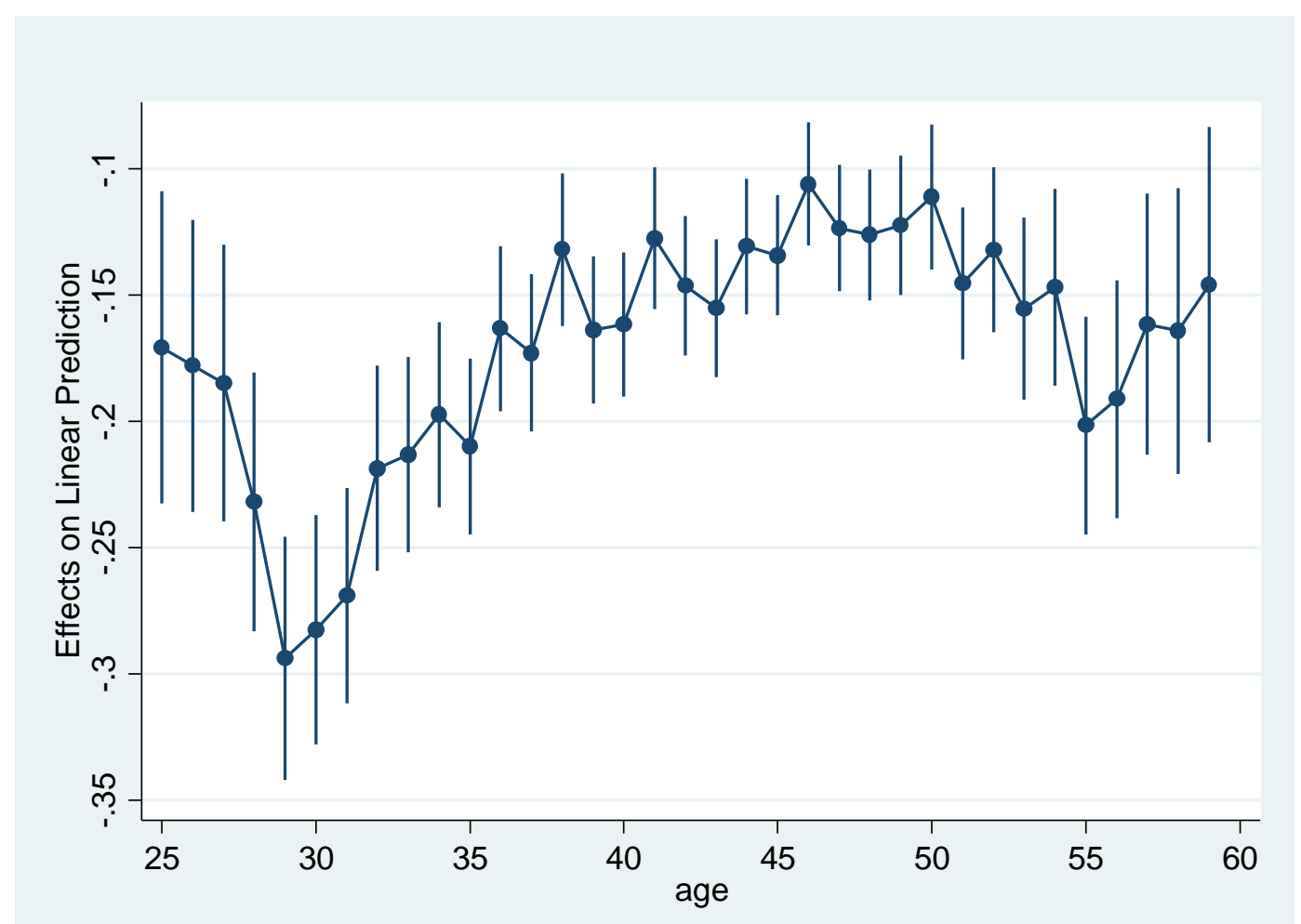

Source: Authors' calculations.

\section{Conclusions}

In this work we study the effect of Social Security Wealth in explaining the individual probability of being in self-employment rather than in employment as well as the probability of switching from self-employment to employment and vice versa. We base our analysis on a large panel of administrative data drawn from the archive of the main Italian Social Security scheme (National Institute of Social Security, Istituto 
Nazionale di Previdenza Sociale, INPS). We use the large exogenous variation in individual Social Security Wealth occurring as a result of the reform process undertaken in Italy during the 1990s to identify its effect on the probability of being self-employed. We concentrate our analysis on the two main categories of self-employed workers craftsmen and shopkeepers - which share the same Social Security rules and can be treated as one single category.

Our empirical strategy is as follows: we compute the expected Social Security Wealth for each individual and at each point in time in the two alternative scenarios of self- and wage-employment, and estimate the effect of the difference in expected SSW on the self-employment rate and on the switching probabilities. We estimate a linear probability model estimated also controlling for other observable determinants and unobserved heterogeneity. Overall, we find that the difference in expected SSW in the two scenarios has an important role in explaining the observed patterns.

In particular, when looking at the self-employment rate, we find that, other things being equal, a 10,000 Euro increase in the difference in expected SSW in the two scenarios increases the probability of being in self-employment by between 0.4 and 0.7 percentage points, depending on the specification. The effect of the difference in SSW on the probability of being a self-employed worker is not independent of age: our estimates show that its effect is highest for young individuals, decreasing for middleaged workers, and increasing again after age 50.

We also estimate the probability of switching to self-employment from employment and vice versa. The results indicate that an increase in the difference in expected SSW in the scenarios of self-employment and employment increases the probability of switching to self-employment from employment, while it reduces the probability of switching to employment from self-employment.

With regard to transitions from employment to self-employment, we find that the effect of the difference in expected SSW is quite sizeable, given that the average probability of switching is very low and equal to $1.3 \%$. The average increase in the difference in SSW after the 1990 and 1995 reforms was about 30,000 Euro while, after the 1992 reform, the difference in SSW increased by about 20,000 Euro. Assuming that these differences are entirely due to the change in Social Security rules, our estimates imply that the effect of these on the probability of switching to self-employment was of almost 0.45 percentage points after the 1990 and 1995 reforms, and almost 0.3 percentage points after the 1992 reform.

Transitions from self-employment to employment are more likely to occur, with an average transition rate equal to $2.8 \%$. The effect of the reforms, implied by our 2SLS-FE estimates, is a reduction in the transition rate of about 0.6 percentage points after the 1990 and 1995 reforms, and about 0.4 percentage points after the 1992 reform. 


\section{Bibliography}

Attanasio, Orazio P., and Agar Brugiavini, 2003. Social Security and Households' Saving. The Quarterly Journal of Economics 118 (3), 1075-1119.

Attanasio, Orazio P., and Susann Rohwedder, 2003. Pension Wealth and Household Saving: Evidence from Pension Reforms in the United Kingdom. American Economic Review, 93(5): 1499-1521.

Belloni, Michele and Rob Alessie, 2009. The importance of financial incentives on retirement choices: New evidence for Italy. Labour Economics 16(5), 578-588

Blanchflower, David G., 2000. Self-employment in OECD countries. Labour Economics 7 (5), 471- 506.

Blanchflower, David G., Oswald, Andrew J., 1990. Self-employment and the enterprise culture. In: Jowell, R.,Witherspoon, S., Brook, L. eds., British Social Attitudes: The 1990 Report. Gower.

Blanchflower, David G., and Oswald, Andrew J., 1998. What makes and entrepreneur? Journal of Labour Economics, 16(1), 26-60.

Blau, David M., 1987. A time-series analysis of self-employment in the United States. The Journal of Political Economy 95 (3), 445- 467.

Borella, Margherita and Flavia Coda Moscarola, 2015. The 2011 Pension Reform in Italy and its Effects on Current and Future Retirees. CeRP Working paper, $151 / 15$.

Borella, Margherita and Flavia Coda Moscarola, 2006. Distributive Properties of Pension Systems: A Simulation of the Italian Transition from Defined Benefit to Notional Defined Contribution, Giornale degli Economisti e Annali di Economia, 65(1), 95-125.

Borella, Margherita and Flavia Coda Moscarola, 2011. Microsimulation of Pension Reforms: Behavioural versus Nonbehavioural, Journal of Pension Economics and Finance, 9(4), 583-607.

Bruce, Donald, 2000. Effects of the United States tax system on transitions into self-employment. Labour Economics 7 (5), 545- 574.

Bruce, Donald, 2002. Taxes and entrepreneurial endurance: Evidence from the self-employed. National Tax Journal, 55(1), 5-24.

Brugiavini, Agar and Franco Peracchi, 2004. Micro-modeling of retirement behavior in Italy. In: Gruber, J., Wise, D. (Eds.), Social Security Programs and 
Retirement Around the World: Micro-Estimation. The University of Chicago Press, Chicago, pp. 345-398. NBER, chap. 6.

Cagetti, Marco, and Mariacristina De Nardi, 2006. Entrepreneurship, Frictions, and Wealth. Journal of Political Economy, 114(5), 835-70.

Crompton, Susan, 1993. The Renaissance of Self-Employment, Perspectives on Income and Employment. Statistics Canada. pp. 22-32, Cat. 75-001E.

Evans, David S., and Boyan Jovanovic, 1989. An Estimated Model of Entrepreneurial Choice under Liquidity Constraints." Journal of Political Economy 97(4), 808-27.

Evans, David S., and Linda S. Leighton, 1989. Some Empirical Aspects of Entrepreneurship. American Economic Review 79(3), 519-35.

Hansson, Asa, 2012. Tax policy and entrepreneurship: empirical evidence from Sweden. Small Bus Econ 38(4), 495-513

Li Yue, Mauro Mastrogiacomo, Stefan Hochguertel, Hans Bloemenx, 2015. The Role of Wealth in the Start-up Decision of New Self-employed: Evidence from A Pension Policy Reform. Nestpar DP 08/2015-026.

Mastrogiacomo, Mauro and Michele Belloni, 2015. Becoming self-employed at ages 50+: true entrepreneurship or exclusion from (wage-)employment? In: A. BörschSupan, H. Litwin, M. Myck, T. Kneip, G. Weber, Ageing in Europe - Supporting Policies for an Inclusive Society. First results from the $5^{\text {th }}$ Wave of the Survey of Health, Ageing and Retirement in Europe, Chapter 22, Berlin, De Gruyter, pp. 245-255, 2015.

OECD 2015. Entrepreneurship at a Glance 2015, August.

Quinn, Joseph F., 1980. Labor force participation patterns of older selfemployed workers. Social Security Bulletin 43, 17-28.

Schuetze, Herb J., 2000. Taxes, economic conditions and recent trends in selfemployment: a Canada-U.S. comparison. Labour Economics 7 (5), 507- 544.

Stabile, Marco, 2004. Payroll taxes and the decision to be self-employed. International Tax and Public Finance, 11(1), 31-53.

Torrini R., 2005. Cross-country differences in self-employment rates: the role of institutions. Labour Economics 12 (5), 661-683.

Zissimopoulos J.M. and L.A. Karoly, 2007. Transitions to self-employment at older ages: The role of wealth, health, health insurance and other factors. Labour Economics, 14 (2), 269-295. 


\section{APPENDIX}

As we perform our analysis using administrative data from the INPS archive, we are interested to know if the fraction of Italian workers covered by INPS is stable over time. In the graph below, we show the percentage of workers covered by the INPS archive over the total number of workers (source: Eurostat) from 1983 to 2012. This demonstrates that the proportion of workers who we follow over time is roughly constant, at around $55 \%$ of the total workers.

Figure A1 - Fraction of workers covered by INPS

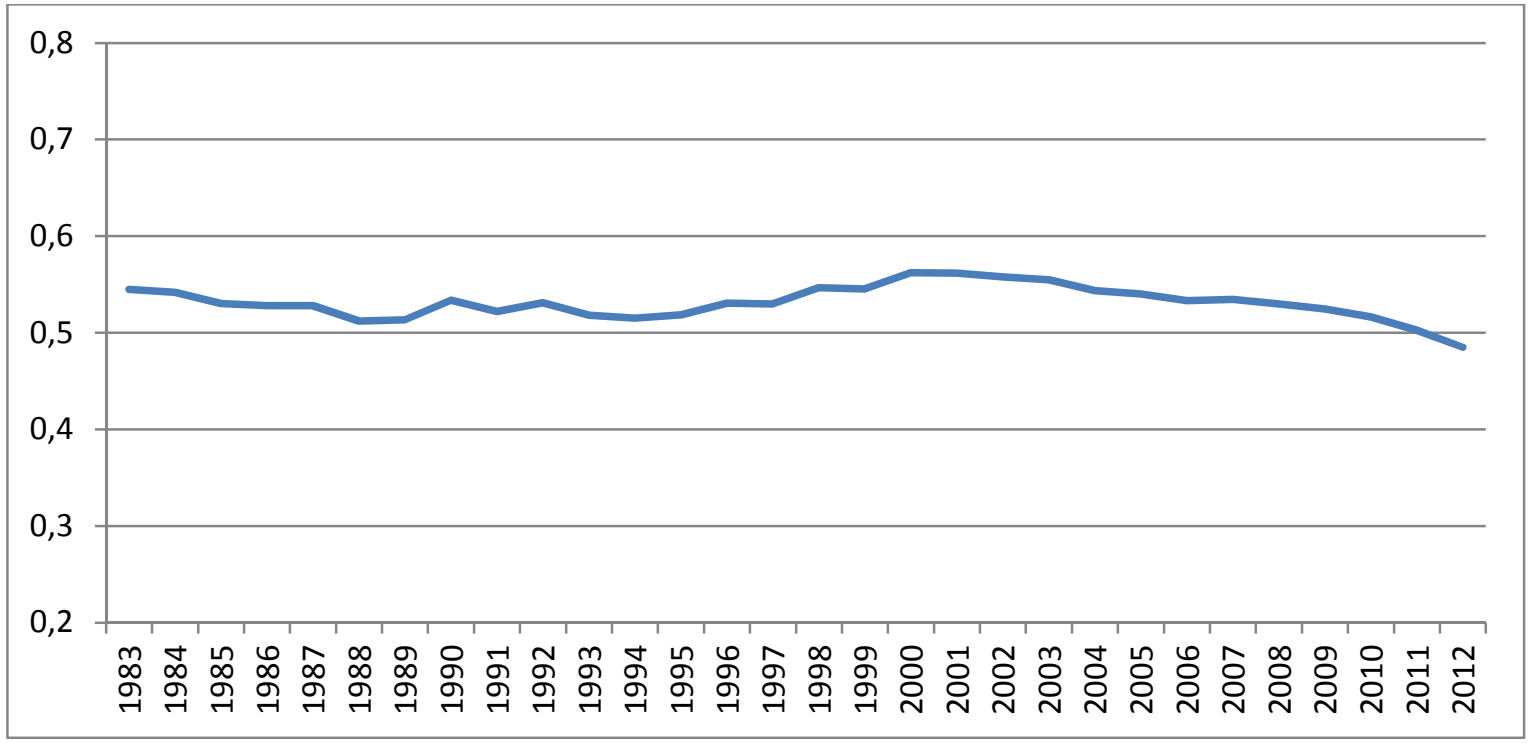

Note: In this graph we show the ratio (expressed as a percentage) of workers covered by the INPS archive and the total number of workers (aged 15+) as recorded by Eurostat.

\section{The Evolution of the Italian pension system}

While the Pension Fund for Private Employees dates back to the beginning of the $19^{\text {th }}$ century, it was respectively in 1959 and in 1966 that craftsmen and shopkeepers began to be covered by Social Security: self-employed workers then became eligible to receive retirement benefits. As a transitory measure, workers were able to apply for pensions with only 1 year of contributions. The payroll contributions for the selfemployed were especially low, set at $12 \%$ of a minimum figurative income until 1973 , when they were slightly raised. In 1982, an additional 4\% computed on actual taxable income was added. The accrued pension benefit, computed with a defined contribution approach, was consequently very low and in most cases it was subsidised to reach the guaranteed minimum pension. In the same years, private employees contributed with a total payroll tax rate of about 20-25 per cent, which then increased over time as 
imbalances of the public pension system became apparent ${ }^{14}$. Their pension benefit was computed with a defined benefit formula and they could, in general, retire earlier than self-employed workers.

An important reform in 1990 profoundly modified the rules, only for selfemployed workers, increasing the contributions paid into the system and transforming benefits, introducing a defined benefit pension formula similar to that applied to employees.

Hence, immediately after the 1990 reform, the pension system was characterised, for all workers, by a defined benefit pension formula, based upon the last few years of earnings or income, without any actuarial correction for age at retirement.

In the main scheme, the Pension Fund for Private Employees (FPLD), the pension was based upon pensionable earnings - computed as the average of the last five years' earnings - multiplied by the number of working years and by the annual accrual rate:

$$
P_{D B}=N * \gamma * \sum_{i=1}^{5} w_{\bar{a}-i+1} / 5
$$

where $\bar{a}$ is the individual's age in his final working year, $w$ is his gross annual earnings indexed for inflation, $\gamma$ is the annual accrual rate (approximately equal to 2 per cent) and $N$ is the number of years the individual has been active in the labour market. For self-employed workers a similar formula applied, with the average income computed over the last ten years of activity.

An important difference between the self-employed and employees was constituted in the old-age requirement, being 65 for the former and 60 for the latter group.

The reform that took place in 1992, whilst preserving the defined benefit system, modified the pension benefit formula for both employees and self-employed workers. For younger workers, pensionable earnings (or income) were planned to be based on the worker's entire earnings history and re-valued at the nominal GDP growth rate. For older workers, a transition phase gradually increasing the period over which pensionable earnings were to be computed was started. Most importantly, the pension indexation mechanism was downgraded from wages to prices for all categories of workers, with immediate effect, causing a sudden reduction in SSW for all workers (as well as pensioners). Such an indexation mechanism has since been maintained by all

${ }^{14}$ With "total payroll tax rate" we refer to the payroll tax rate paid both by the worker approximately one-third of the total - and by the employer. 
subsequent reforms. In addition, eligibility requirements for employees were gradually tightened.

Another reform, approved in 1995, rescheduled a new (and lengthy) transition towards an NDC formula. When the new system is phased in, benefits will be commensurate to the amount of payroll taxes paid, capitalised at an interest rate equal to the growth rate of the GDP and annuitized according to life expectancy at retirement.

The reforms of 1992 and 1995 thus opened a lengthy transition period which will end in 2030. Until then, in fact, the rules for accessing retirement and for calculating the pension benefit will evolve differently for different generations of workers. In particular, three groups can be distinguished:

1 - workers who accumulated at least 18 years of service at the end of 1995: the pension for these workers is calculated with the DB rules as modified by the 1992 reform. The age requirements for retirement have also been raised. Hence a Modified Defined Benefit (MDB) applies to these workers; ${ }^{15}$

2 - workers who started contributing to the pension system before 1995 but accumulated less than 18 years of contributions at the end of 1995: for these workers the pension is calculated with a pro rata (PR) system. The first part of the pension covers the seniority accrued up to the end of 1995 and is calculated with the DB formula. The second part of the pension instead refers to seniority accrued after 1995 and is calculated with the NDC formula.

3 - workers who entered the labour market since January 1, 1996: the NDC system fully applies to these workers.

The above classification applies to both the self-employed and employees, although there are still differences in the computation of pensionable earnings, in the payroll tax rates and in legal retirement ages.

It is useful to describe the above mentioned pension formulae for the computation of the benefits, as the results of our analysis are largely based upon them. In the MDB system, the benefit depends upon pensionable income, i.e. average income earned at the end of the career. As a consequence of the 1992 reform, the benefit consists of two parts, in which pensionable income is computed taking the average over a longer period for seniority accrued after 1992. Apart from this complication, the MDB check is a traditional defined benefit pension computed as:

$$
P_{M D B}=\alpha *\left(c_{1} W_{1}+c_{2} W_{2}\right)
$$

15 A further reform in 2011 modified the rules for this group of workers, adding a pro-rata component to their pension benefit starting from 2012. As our analysis stops before 2011, we do not discuss this reform in detail. See Borella and Coda Moscarola (2015) for an analysis of the 2011 reform. 
Where $\mathrm{W}_{1}$ and $\mathrm{W}_{2}$ is pensionable income, i.e. average income over the last five $\left(\mathrm{W}_{1}\right)$ or ten $\left(\mathrm{W}_{2}\right)$ years of the working career (ten to fifteen for the self-employed), revalued in line with inflation $\left(\mathrm{W}_{1}\right)$ or nominal GDP growth $\left(\mathrm{W}_{2}\right)$, and $c_{1}$ and $c_{2}$ are the years of contribution accrued before and after 1992 respectively. The annual accrual rate $\alpha$ is equal to 2 per cent up to a certain threshold, gradually reduced for higher pensionable incomes.

The NDC pension, for all categories of workers, is computed as:

$$
P_{N D C}=\left(\sum_{i=\underline{a}}^{\bar{a}} C_{i} *(1+g)^{\bar{a}-i}\right) \cdot \delta_{\bar{a}+1}
$$

where $\mathrm{C}_{i}$ is the contribution paid by the worker at age $i, g$ is the five years moving average of the nominal GDP growth rate, $\delta$ is an age-specific annuity rate, $\underline{a}$ is the age at which the worker entered the labour market and $\bar{a}$ is the individual's age in his final working year. In other words, the pension benefit in the NDC system is equal to the notional capital, i.e. the sum of all contributions paid, re-valued to a rate equal to the five years moving average of the nominal GDP growth rate, multiplied by an agespecific coefficient $\delta$. The annuity rates $\delta$ are set by law as the inverse of the present value at retirement of a one unit annuity benefit and they are updated according to life expectancy. The NDC pension formula fully applies to NDC workers, who entered the labour force after 1/1/1996. During the transition, i.e. for workers already active in the labour force in 1995, the pension benefit will be computed with a pro rata mechanism, as a weighted average of the MDB and NDC check, with the weights given by years of seniority accrued before and after 1/1/1996.

Due to the length of the transition, numerous legislative measures have gradually raised the requirements for access to retirement, but without changing the method of calculating the pension.

Payroll tax rates have also been raised by the various reforms, reaching 32.7 per cent for employees and 17.2 per cent for the self-employed in the year 2005, the last year considered in our analysis.

\section{Hypotheses in the computation of the Present Values and expected SSW}

To compute future pension entitlements and expected SSW we use the official ISTAT mortality tables from 1985 to 2005. As for the macroeconomic variables, we set the interest rate, inflation rate and GDP real growth rate at their historical levels up to the year 2013. For the future they are set at 2 per cent, 1.6 per cent and 1.5 per cent, respectively. The real discount rate is also set at 1.5 per cent. 


\section{Summary statistics for regression variables}

Table A1 - summary statistics for variables included in the regressions, pooled data

\begin{tabular}{|l|c|c|}
\hline & Mean & Standard Deviation \\
\hline self & 0.258 & 0.438 \\
$S S W_{i t+1}^{S E}\left(y_{t+1}\right)-S S W_{i t+1}^{W E}\left(y_{t+1}\right)$ & 0.026 & 0.053 \\
$S S W_{i t+1}^{S E}\left(y_{t}\right)-S S W_{i t+1}^{W E}\left(y_{t}\right)$ & 0.026 & 0.048 \\
PV $(\mathrm{Y})_{\mathrm{t}}$ & 0.827 & 0.401 \\
Experience & 19.015 & 9.615 \\
Out of work & 0.182 & 0.188 \\
Sick or unemployed & 0.073 & 0.117 \\
Age & 38.810 & 8.701 \\
\hline
\end{tabular}

Note: the number of observations is 9,288,651. These are summary statistics referring to the estimates shown in Table 3 in the main text. All monetary values are expressed in millions of Euro at 2013 prices. 


\section{Latest CeRP Working Papers}

\begin{tabular}{|c|c|}
\hline $\mathrm{N}^{\circ} 159 / 16$ & $\begin{array}{l}\text { Margherita Borella } \\
\text { Michele Belloni }\end{array}$ \\
\hline$N^{\circ} 158 / 16$ & Claudio Morana \\
\hline $\mathrm{N}^{\circ} 157 / 16$ & $\begin{array}{l}\text { Riccardo Calcagno } \\
\text { Maela Giofré } \\
\text { Maria Cesira Urzì-Brancati }\end{array}$ \\
\hline$N^{\circ} 156 / 16$ & $\begin{array}{l}\text { Elisa Luciano } \\
\text { Mariacristina Rossi } \\
\text { Dario Sansone }\end{array}$ \\
\hline$N^{\circ} 155 / 16$ & Claudio Morana \\
\hline$N^{\circ} 154 / 15$ & Vincenzo Andrietti \\
\hline$N^{\circ} 153 / 15$ & $\begin{array}{l}\text { Donatella Baiardi } \\
\text { Claudio Morana }\end{array}$ \\
\hline$N^{\circ} 152 / 15$ & $\begin{array}{l}\text { Ewa Gałecka-Burdziak } \\
\text { Marek Góra }\end{array}$ \\
\hline $\mathrm{N}^{\circ} 151 / 15$ & $\begin{array}{l}\text { Margherita Borella } \\
\text { Flavia Coda Moscarola }\end{array}$ \\
\hline $\mathrm{N}^{\circ} 150 / 15$ & Anna Lo Prete \\
\hline$N^{\circ} 149 / 15$ & $\begin{array}{l}\text { Flavia Coda Moscarola } \\
\text { Ugo Colombino } \\
\text { Francesco Figari } \\
\text { Marilena Locatelli }\end{array}$ \\
\hline $\mathrm{N}^{\circ} 148 / 15$ & $\begin{array}{l}\text { Flavia Coda Moscarola } \\
\text { Elsa Fornero } \\
\text { Steinar Strøm }\end{array}$ \\
\hline $\mathrm{N}^{\circ} 147 / 14$ & $\begin{array}{l}\text { Matteo Morini } \\
\text { Simone Pellegrino }\end{array}$ \\
\hline$N^{\circ} 146 / 14$ & $\begin{array}{l}\text { Mariacristina Rossi } \\
\text { Eva Sierminska }\end{array}$ \\
\hline $\mathrm{N}^{\circ} 145 / 14$ & $\begin{array}{l}\text { Johannes G. Hoogeveen } \\
\text { Mariacristina Rossi } \\
\text { Dario Sansone }\end{array}$ \\
\hline $\mathrm{N}^{\circ} 144 / 14$ & Elsa Fornero \\
\hline $\mathrm{N}^{\circ} 143 / 14$ & $\begin{array}{l}\text { Kees de Vaan } \\
\text { Daniele Fano } \\
\text { Herialt Mens } \\
\text { Giovanna Nicodano }\end{array}$ \\
\hline $\mathrm{N}^{\circ} 142 / 14$ & $\begin{array}{l}\text { Elisabetta Cagna } \\
\text { Giulio Casuccio }\end{array}$ \\
\hline
\end{tabular}

Self-Employment in Italy: the Role of Social Security Wealth

Macroeconomic and Financial Effects of Oil Price Shocks: Evidence for the Euro Area

To trust is good, but to control is better: how do investors discipline financial advisors' activity

Financial Inclusion and Life Insurance Demand; Evidence from Italian households

The US\$/€ exchange rate: Structural modeling and forecasting during the recent financial crises

Auto-enrollment, Matching, and Participation in 401(k) Plans

Financial deepening and income distribution inequality in the euro area

The impact of easy and early access to old-age benefits on exits from the labour market: a macro-micro analysis

The 2011 Pension Reform in Italy and its Effects on Current and Future Retirees

Labour market institutions and household consumption insurance within OECD countries

Shifting Taxes from Labour to Property. A Simulation under Labour Market Equilibrium

Absenteeism, Pension Reforms and Grandmothers

Personal Income Tax Reforms: a Genetic Algorithm Approach

Single again? Asset and portfolio changes due to widowhood shock

Drivers of performance in primary education in Togo

Economic-financial literacy and (sustainable) pension reforms: why the former is a key ingredient for the latter

A Reporting Standard for Defined Contribution Pension Plans

Equally-weighted Risk Contribution Portfolios: an empirical study using expected shortfall

The full series is available at: http://www.cerp.carloalberto.org/category/publications/working-papers/ 